\title{
ENVIRONMENTAL HAZARDS AND RISK MANAGEMENT IN THE FINANCIAL SECTOR: A SYSTEMATIC LITERATURE REVIEW
}

\author{
Miriam Breitenstein \\ Technische Universität Dresden \\ Duc Khuong Nguyen (iD \\ IPAG Business School \\ and International School, Vietnam National University (Hanoi) \\ Thomas Walther* (iD) \\ Technische Universität Dresden \\ and Utrecht University
}

\begin{abstract}
We conduct a systematic literature review on environmental and climate-related risk management in the financial sector. We classify the current literature into three categories: (i) the impact of environmental concerns on financial risk; (ii) the current state of environmental risk practices in the financial sector; and (iii) measures to assess the financial exposure to environmental risks. We find that financial institutions can reduce their risk exposure by highly committing with environmental responsibility and performance. Moreover, the increase in willingness to assess climate-related financial risk incentivizes corporate managers to adopt more proactive environmental policies and practices.
\end{abstract}

Keywords. Banking; Climate; Environment; Financial Institutions; Risk Management

\section{Introduction}

As science and society become increasingly aware of the risks that climate change can induce, the impact of environmental hazards on the financial sector subsequently comes into focus. Financial institutions are exposed to these climate or environment-related financial risks through their loan portfolios and other invested capital. Investment decisions and environmental risk management thus need to take exposures to environmental hazards into account (Boermans and Galema, 2019; Braun et al., 2019). The Carbon Disclosure Project (2019) reports that the financial sector estimates U.S.\$693 billion at risk from climate change impacts and that most of the risks are going to materialize within the next five years. Dietz et al. (2016) find an expected "climate Value-at-Risk" of U.S.\$2.5 trillion for global financial assets

*Corresponding author contact email: t.walther@uu.nl. Tel. +31 (0)30 2539810.

Journal of Economic Surveys (2021) Vol. 00, No. 00, pp. 1-27

(C) 2021 The Authors. Journal of Economic Surveys published by John Wiley \& Sons Ltd

This is an open access article under the terms of the Creative Commons Attribution-NonCommercial-NoDerivs License, which permits use and distribution in any medium, provided the original work is properly cited, the use is non-commercial and no modifications or adaptations are made. 
under their business as usual scenario. Similarly, Battiston et al. (2017) emphasize on the existence of an interdependence between exposure of financial portfolios and climate policy.

To date, environmental issues have increasingly gained attention from financial sector actors. Corporations started addressing their exposures to climate change and other environmental hazards by enabling banks and insurance companies to access relevant data (Ilhan et al., 2020a). Institutional investors established organizational dedicated frameworks, strategies, and research for environmental issues and related risks. For example, the Climate Action 100 or Global Investor Coalition on Climate Change call for carbon pricing in order to more adequately allocate capital across lesser environmental risk-impacted investments (De Jong and Nguyen, 2016; Krueger et al., 2020). However, while financial institutions recognize environmental risks, studies find that they encounter difficulties with regards to data availability, to pricing and hedging of environmental risks, and appropriate assessment within their risk management (G20 Green Finance Study Group, 2017; Basel Committee on Banking Supervision, 2020; Krueger et al., 2020). Individual issues of climate-related risk faced at the institutional level might sum up to a systemic vulnerability of the financial system and thus become relevant to national central banks and supervisors (Batten et al., 2016; Campiglio et al., 2018). Central banks and supervisors have warned of climate risks and highlighted the importance of the financial risk assessment and management in banks as this can mitigate the threats of climate change on the financial industry (Bank of England and Banque de France, 2019; NGFS, 2019). Despite considering climate change hazards as financial risk, the European Central Bank (ECB) fails to account for environmental risks and excludes it in both, supervision and monetary policy (Sustainable Finance Lab, 2018).

In this paper, we examine the fundamental research on the environmental risk and its impact on financial performance, current practices of environmental risk management within the financial sector, and tools to assess or hedge environmental risk. We particularly focus on two questions. First, how is environmental risk approached to and practiced within the current risk management framework in the financial industry? Second, what are the current challenges to environmental risk management and sustainable businesses? We also discuss research paths that can potentially be investigated in future research. To accomplish our objective, a systematic literature review is conducted to identify and discuss relevant quality research. Our literature review presents evidence of dependency of a firm's financial risk on environmental concerns and its engagement in environmental responsibility. The reason is that firms with environmental responsibility and higher environmental performance exhibit lower market risk characteristics. Moreover, environmental risks are found to be negatively associated with financial performance. In addition, we find that current practices of environmental risk assessment indicate a clear increase in awareness and willingness to assess climate-related financial risk. The latter has shifted from no recognition of financial impacts of environmental risks in 2011 to advanced knowledge about the urgency to address climate risks in financial institutions in 2018. Another important fact is that most investors face difficulties when approaching climate-related financial risk since the basic approaches such as carbon footprint analyses are not efficient enough. The issues and challenges ahead include disclosure of firm data, suitable assessment, and pricing instruments.

Our findings have important implications for corporate environmental behavior, to the extent that investors pay more attention to financial risk and performance effects of environmental quality. This can lead to positive changes in attitudes toward environment and environmental protection intentions of corporate executives and managers, which push firms to more proactive environmental practices. For instance, Liston-Heyes and Vazquez Brust (2016) show, from a multistage model of corporate environmental behavior where environmental attitudes are allowed to directly affect firms' environmental intentions and performance, that pressures from stakeholders can lead to the development of managerial proenvironmental attitudes.

The rest of the paper is structured as follows. Section 2 briefly reviews the concept of environmental risk and hazards as well as the theoretical foundations of risk management processes in financial institutions. Section 3 introduces the systematic literature research approach and presents a preliminary

Journal of Economic Surveys (2021) Vol. 00, No. 00, pp. 1-27

(C) 2021 The Authors. Journal of Economic Surveys published by John Wiley \& Sons Ltd 
quantitative analysis of the research identified. Section 4 provides insights into the impact of environmental risk on financial performance and current practices of environmental risk management in the financial sector. Section 5 presents possible paths for further research. Concluding remarks are provided in Section 6.

\section{Theoretical Background}

As far as the research topic of environmental risk management is concerned, critical issues such as financial risk management and the framework of environmental hazards as well as its classification within the financial sector are of paramount importance.

Taking risk management within the financial sector into consideration, European regulations have been developed to ensure compliant protection against financial risks. Several regulatory mechanisms are equally employed to improve financial risk management. For example, the Basel Accords ensure capital requirements for market and credit risks, which are among the essential components of risk management. Solvency II presents a risk-based capital regulation framework that applies to insurance companies (Gatzert and Wesker, 2012). It is however worth noting that Basel III currently supports risk management in taking a short-term view on financial risk, which contradicts the long-term impacts of climate-related risks (D'Orazio and Popoyan, 2019).

With respect to the analysis of risk, Muralikrishna and Manickam (2017) highlight the process of identifying and assessing environmental risk. It consists of several steps starting with the problem formulation which serves as a basis for the subsequent identification of the adequate risk assessment type and level. Accordingly, it is essential to define the problem, its boundaries and the constraints of the assessment. This step also involves the modeling of the source-pathway-receptor relation that describes the course of risk from the hazard to the eventually affected group of receptors. An example for this modeling could be rainfall (hazard) that causes high water in rivers followed by overtopping, failure of flood defenses, and inundation (pathways), and ultimately harms infrastructure, private/public properties, people, and possibly the ecosystem as well (receptors). Risk assessment contains two key components, namely, hazard assessment and environmental exposure assessment. Hazard assessment addresses the identification of the potential adverse impact on receptors through collecting and evaluating relevant data. The exposure assessment identifies the direct/indirect vulnerability to the hazards (e.g., chemicals) and defines to what extent (e.g., dose, concentration) the human population, environment, or industry sector is exposed to. These analyses feed into risk characterization which qualitatively and quantitatively determine the chance and extent of harmful impact to receptors under hazard exposures.

In this context, the term "environmental hazards" defines threats to humans or nature that are potentially caused by the natural or built environment. This research topic has recently received increased attention because environmental threats develop through climate change and they are voluntarily encouraged by humans under societal pressures (Smith, 2004). Few different concepts were developed to define and classify these environmental sources of risk (Smith, 2004; Caldecott and McDaniels, 2014; Bank of England, 2015). This literature review follows Cambridge Centre for Sustainable Finance (2016) and Mercer Investment Consulting (2015) in classifying environmental hazards.

The Cambridge Centre for Sustainable Finance defines a broad categorization of environmental hazards. Banks are exposed to financial risk caused by acute or chronic physical environmental events but also to appertaining risks of transition (Cambridge Centre for Sustainable Finance, 2016). This framework has originally been developed by Mercer Investment Consulting (2015) which outlines the socalled Technology, Resource Availability, Impact of Physical Damages, Policy (TRIP) framework in more details. The TRIP framework divides the previously mentioned physical events into resource availability and physical damages. Catastrophic physical damages represent "acute" physical events such as floods or hurricanes. Resource availability comprises all "chronic" and long-term environmental changes having

Journal of Economic Surveys (2021) Vol. 00, No. 00, pp. 1-27

(C) 2021 The Authors. Journal of Economic Surveys published by John Wiley \& Sons Ltd 


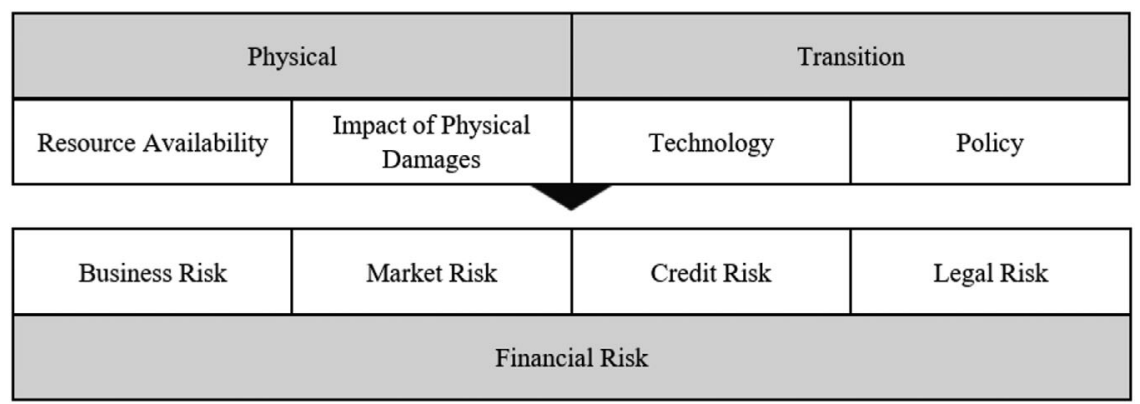

Figure 1. Categorization of Environmental Risk Sources and Conformity of TRIP Framework and G20 Approach (Cambridge Centre for Sustainable Finance, 2016).

an impact on investments. It includes impacts that are initially caused by climate change such as water scarcity and changes in weather patterns. These weather patterns may result in positive as well as negative impacts at different times of development. Moreover, the category of transition hazards is split into policy and technology categories. As climate change increasingly influences political decisions, policies, and economic developments, banks are not only affected by the environment itself but also by climate change transition. The policy risk source, which is related to both national and international measures to support energy transformation and reduce the steady impact of climate change, implies different kinds of legislation, regulation, mandates, or targets concerning direct and indirect pricing mechanisms, and research and development. ${ }^{1}$

Further classification differentiates between demand-side and supply-side policies aiming at either promoting low-carbon alternatives or reducing carbon emissions. On the supply side, low-carbon technologies and products are encouraged to provide consumers with less carbon-intensive products and services. On the demand side, implemented policies decrease the consumption of high-carbon products through pricing or nonmonetary disincentives (e.g., labeling). Finally, technological hazards include technological advancement, disruption, and changes in the energy, specifically low-carbon, industries. The focus is on technologies to transform, transmit, and use energy (Mercer Investment Consulting, 2015).

These environmental hazards eventually result in specific financial risks that - in this case - are faced by institutions in the financial sector. There is no consistent distinction between financial and nonfinancial risk in literature. Financial risk implies an adverse impact on the profitability of a financial institution through, for example, an increase in costs or a decrease in revenues. Through climate change, financial risk exhibits specific distinctive characteristics. Within the financial sector's classification of risk, environmental hazards affect the key risk areas (business, market, credit, and legal risk) as identified by Cambridge Centre for Sustainable Finance (2016). Figure 1 gives an overview of the different categories of hazards that can impact the outlined categories of financial risk.

\section{Systematic Literature Review}

\subsection{Methodology}

The systematic literature review is based on the procedure of Tranfield et al. (2003). It begins with the identification of suitable keywords and search terms resulting from the research question and the literature that has been reviewed up to that point. In addition, only publications with a publication

Journal of Economic Surveys (2021) Vol. 00, No. 00, pp. 1-27

(C) 2021 The Authors. Journal of Economic Surveys published by John Wiley \& Sons Ltd 
date starting in 2008 are examined in order to identify current approaches to environmental risk management. ${ }^{2}$ This time frame follows the study by Delis et al. (2020) who argue for the novelty of this research strand. The number of search results in Figure A.1 in the Appendix witnesses the increased frequency of this topic starting from 2008. The keywords used are intended to identify approaches to assess and manage environmental risks in the financial sector, specifically banks. Consequently, the keywords contain synonyms related to environmental risks themselves (e.g., climate risk, climate-related risk, climate change risk, environmental risk, environmental, social, and governance [ESG] risk, and transition risk) as well as synonyms related to concepts of management (e.g., approach, assessment, and management). In our study, we focus on risk management and thus did not include studies connected to ESG disclosure in the literature review, unless linked to specific terms of risk management. Moreover, the search includes keywords related to the financial sector and uses relevant synonyms (e.g., bank, banking, banking industry, banking sector, financial industry, financial institution, financial sector, and institutional investor). The search strings connect these three categories with the Boolean operator AND and additionally refer to the use of the truncation " $*$," if possible. This minimizes the number of searches to be carried out and double counting. These search strings are quite precise in order to focus on environmental risks and exclude other climate change-relevant topics that do not deal with risk management concepts.

Table A. 2 provides an overview of the associated number of search results. The search is conducted on the three electronic databases EBSCOhost, Emerald Insight, and ScienceDirect, whereby for EBSCOhost the sub databases "Business Source Complete" and "EconLit with Full Text" are used. The use of these three different databases, in turn, ensures the holistic and comprehensive nature of the research and is intended to prevent subject-relevant literature from not being recorded in the search due to limitations of individual databases.

Using suitable inclusion and exclusion criteria, the results of the search are filtered according to their relevance. For this purpose, the title and abstract of all articles are reviewed and examined with regard to the defined criteria. In this way, literature that is not sufficiently concerned with the subject is excluded. In order to create a shortlist, a detailed full-text analysis is carried out in the next step. The result is a list of articles that are thematically relevant to the research question considered. All articles of the narrower selection are then evaluated in terms of its scientific quality and, if necessary, further filtered in order to guarantee an adequate quality of the underlying data. In particular, the use of the journal ranking JOURQUAL 3.0 is appropriate in terms of its scientific relevance and international recognition. ${ }^{3}$ The final outcome is a selection of publications that meet the previously defined standards in terms of both content and scientific quality.

After entering the search strings, a total of 378 potentially relevant English-language publications could initially be identified, of which 296 were published from 2008 onward and thus meet the first two selection criteria (including duplication). By gradually analyzing the titles, abstracts, and keywords of all 296 studies identified, a narrower selection of sources could first be determined, which was subsequently subjected to a full-text analysis to exclude subject-irrelevant research. In this way, the selection could be limited to 64 articles. Removing duplication eventually led to an interim result of 35 articles relevant to the content. In the final step of literature selection, the corresponding journals were evaluated with regard to the JOURQUAL 3.0 rating. In order to ensure the quality of the scientific statements in this work, only articles with a rating of at least $\mathrm{C}$ are further considered. Finally, we yield a selection of 19 relevant articles meeting all four of the above-specified selection criteria. Figure 2 summarizes the procedure scheme of the literature research including the articles left after each step. ${ }^{4}$

In order to collect further subject-relevant literature, a backward reference search, also referred to as snowball principle, is carried out. It specifically analyzes the bibliography of each study. We start the systematic snowball literature search with Ilhan et al. (2020a). The criteria for choice of literature remain mostly unchanged, focusing on English literature from 2008 onward and relying on scientific publications in journals with a JOURQUAL 3.0 rating of at least C. ${ }^{5}$ It is important to note that three quality working

Journal of Economic Surveys (2021) Vol. 00, No. 00, pp. 1-27

(C) 2021 The Authors. Journal of Economic Surveys published by John Wiley \& Sons Ltd 


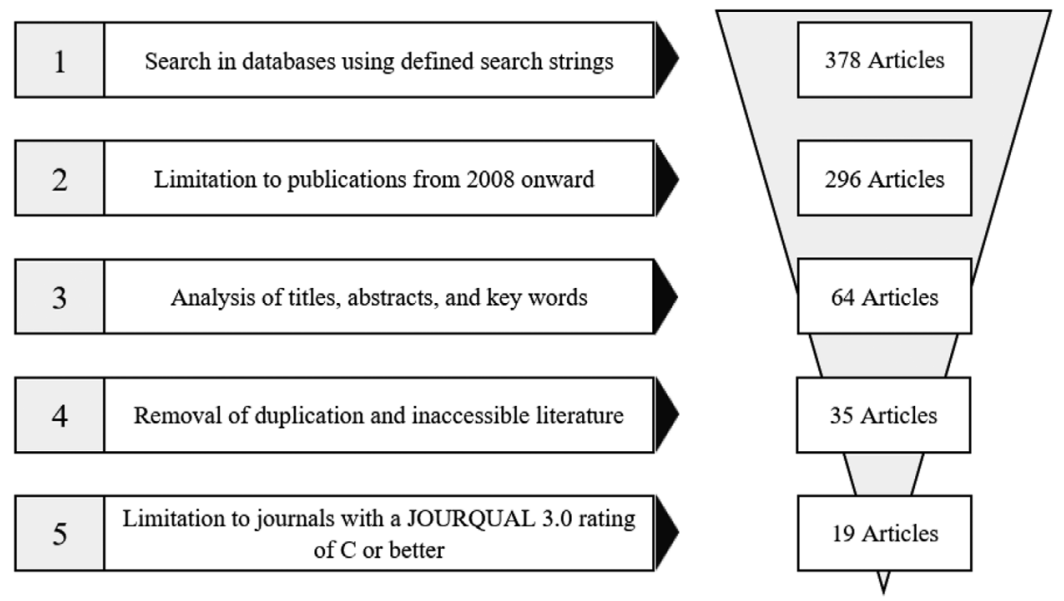

Figure 2. Process Scheme of the Systematic Literature Research.

papers have been included in this research selection. Appearing later on in the snowball research, Krueger et al. (2020) cover literature resulting from the Review of Financial Studies (RFS) Climate Finance Initiative to a great extent. The RFS Climate Finance Initiative encourages further research in the field of climate finance, including environmental risk management. Since the RFS obtains an A+ rating and the corresponding literature is already conditionally accepted, the snowball literature review also considers publications from the RFS Climate Finance Initiative. Excluding already identified publications through the previous literature research, the snowball principle research adds 19 articles to the existing list of results, leading to a total of 38 articles in our final sample. We provide a list of our sample and a more detailed summary of the process in Table A.1 and A.3, respectively.

\subsection{Quantitative Results of the Literature Review}

Following the explanation of the general methodology and the precise approach of literature research, the results of our study are reviewed hereafter. Before examining what are the current challenges to environmental risk management and considering the state of research, a brief analysis of the general characteristics of the selected literature is carried out. Such an analysis is important in order to classify the statements expressed in the literature in terms of their scientific quality and relevance to the subject, and thus to enable a better interpretation of the results.

Figure 3 illustrates the JOURQUAL 3.0 ratings of the final articles. Most of the literature identified within literature research, namely, $64 \%$, have been ranked with at least B or above. It is important to highlight the high number of journals with an A-rating or higher (29\%), which ensures a high quality of the studies examined. Within the range of journals classified as outstanding and world-leading, it is striking that six studies originate from the RFS Climate Finance Initiative eventually being published in the RFS. However, the results of the literature also include eight studies that only have a rating of $\mathrm{C}$ and are thus titled "recognized scientific journals." Note also that four of the selected articles have not been published in a scientific journal and are therefore left without a ranking.

The studies can be classified according to the subject area of the journals in which they are published. Most studies appear in journals with a specific relation to the thematic field of financing and banking. This finding matches with the formulated research questions that aim at environmental risk management in the financial sector. As the consideration of financial risk also evolves from an increased sustainability

Journal of Economic Surveys (2021) Vol. 00, No. 00, pp. 1-27

(C) 2021 The Authors. Journal of Economic Surveys published by John Wiley \& Sons Ltd 


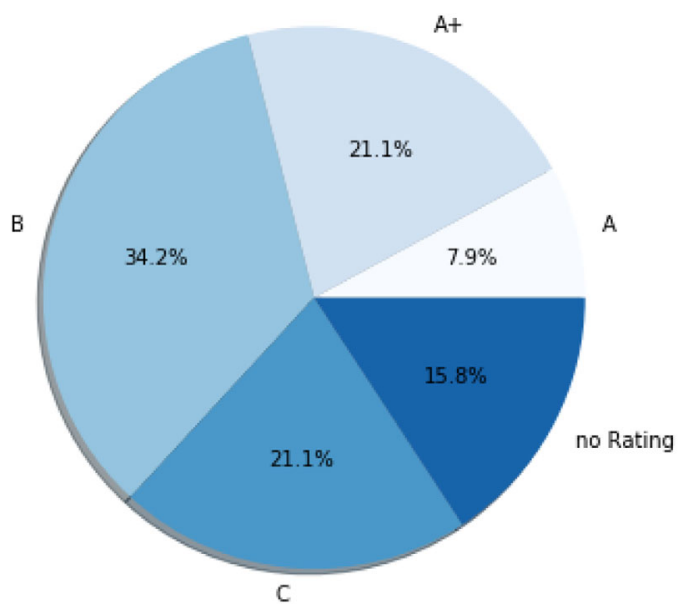

Figure 3. JOURQUAL 3.0 Ratings and Number of Journals of Final Selection. [Colour figure can be viewed at wileyonlinelibrary.com]

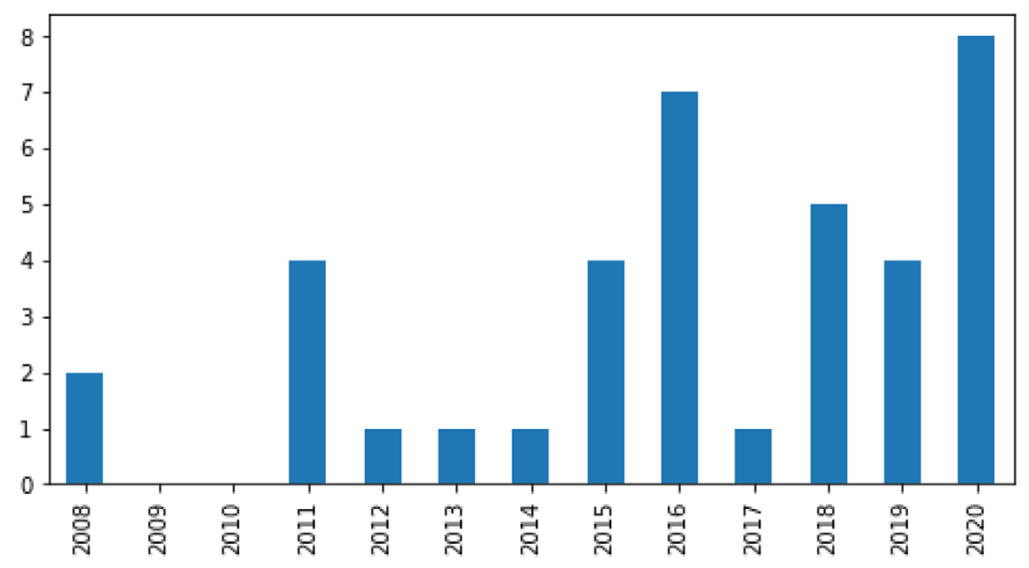

Figure 4. Chronology of Relevant Research Literature with Corresponding Number of Studies. [Colour figure can be viewed at wileyonlinelibrary.com]

and climate change awareness of the financial sector, around nine studies can be assigned to the category of sustainability management. At the same time, the subject seems to be highly relevant for corporate management due to the comparatively high number of articles in the management area. Figure 4 presents the distribution of the articles over time. We find an increase in relevant literature starting around 2015 which marks the year of the 2015 Paris Climate Conference.

\section{Research in Environmental Risk and Current Approaches to Environmental Risk Management}

This section reviews the current approaches of scientific and business practices to assess environmental risks. It conduces to create a comprehensive understanding of current challenges and potential paths of research that are addressed in Section 5. 
Table 1. Overview and Classification of Studies Extracted from the Systematic Literature Research.

\begin{tabular}{|c|c|c|c|c|}
\hline No. & Author & $\begin{array}{c}\text { Impact of } \\
\text { environmental risk }\end{array}$ & Current practices & Assessment \\
\hline 1 & Addoum et al. (2020) & $\mathrm{X}$ & & \\
\hline 2 & Alok et al. (2020) & & $\mathrm{X}$ & \\
\hline 3 & Barnett et al. (2020) & & & $\mathrm{X}$ \\
\hline 4 & Delis et al. (2020) & $\mathrm{X}$ & & \\
\hline 5 & Engle et al. (2020) & & & $\mathrm{X}$ \\
\hline 6 & Ilhan et al. (2020a) & & $\mathrm{X}$ & \\
\hline 7 & Ilhan et al. (2020b) & $\mathrm{X}$ & & \\
\hline 8 & Krueger et al. (2020) & & $\mathrm{X}$ & \\
\hline 9 & Addoum et al. (2019) & $\mathrm{X}$ & & \\
\hline 10 & D’Orazio and Popoyan (2019) & & & $\mathrm{X}$ \\
\hline 11 & Görgen et al. (2019) & & & $\mathrm{X}$ \\
\hline 12 & Hong et al. (2019) & & $\mathrm{X}$ & \\
\hline 13 & Eccles and Krzus (2018) & $\mathrm{X}$ & & \\
\hline 14 & Huang et al. (2018) & $\mathrm{X}$ & & \\
\hline 15 & Jung et al. (2018) & $\mathrm{X}$ & & \\
\hline 16 & Nguyen (2018) & $X$ & & \\
\hline 17 & Thistlethwaite and Wood (2018) & & $\mathrm{X}$ & \\
\hline 18 & Fernando et al. (2017) & $X$ & & \\
\hline 19 & Andersson et al. (2016a) & & $\mathrm{X}$ & \\
\hline 20 & Andersson et al. (2016b) & & & $\mathrm{X}$ \\
\hline 21 & Bansal et al. (2016) & & & $\mathrm{X}$ \\
\hline 22 & De Jong and Nguyen (2016) & & & $\mathrm{X}$ \\
\hline 23 & Sassen et al. (2016) & $\mathrm{X}$ & & \\
\hline 24 & Semenova and Hassel (2016) & $\mathrm{X}$ & & \\
\hline 25 & Verheyden et al. (2016) & $X$ & & \\
\hline 26 & Georgopoulou et al. (2015) & & & $\mathrm{X}$ \\
\hline 27 & Kim et al. (2015) & $\mathrm{X}$ & & \\
\hline 28 & Muhammad et al. (2015) & $\mathrm{X}$ & & \\
\hline 29 & Nikolaou et al. (2015) & $\mathrm{X}$ & & $\mathrm{X}$ \\
\hline 30 & Chava (2014) & $\mathrm{X}$ & $\mathrm{X}$ & \\
\hline 31 & Flammer (2013) & $\mathrm{X}$ & & \\
\hline 32 & Weber (2012) & & $\mathrm{X}$ & \\
\hline 33 & Campbell and Slack (2011) & & $\mathrm{X}$ & \\
\hline 34 & Litterman (2011) & & $\mathrm{X}$ & \\
\hline 35 & Salama et al. (2011) & $X$ & & \\
\hline 36 & Solomon et al. (2011) & & $\mathrm{X}$ & \\
\hline 37 & Sharfman and Fernando (2008) & $\mathrm{X}$ & & \\
\hline 38 & Weber et al. (2008) & & $\mathrm{X}$ & \\
\hline
\end{tabular}

We conduct a qualitative coding through content analysis to draw conclusions from the systematic literature review. In this regard, a categorical framework outlines and classifies the extracted studies. The overview presented in Table 1 shows the key topics and research aspects of each study. The articles are classified into three categories:

Journal of Economic Surveys (2021) Vol. 00, No. 00, pp. 1-27

(C) 2021 The Authors. Journal of Economic Surveys published by John Wiley \& Sons Ltd 
1. The impact of environmental risk: this category comprises studies which address the relationship between environmental risks, environmental engagement, and financial performance.

2. Current practices: this category covers studies that either outline current practices of environmental risk management or propose approaches to assess the relevance of environmental hazards in the financial sector.

3. Environmental risk assessment: this category includes studies with focus on measuring the impact of environmental hazards.

Presented chronologically by date of publication, Table 1 highlights the distribution of thematic aspects of research. For example, research in environmental risk assessment only starts 2015, whereas the other topics are rather spread over the chosen time period of literature research starting in 2008. In what follows, we successively review these three categories of research.

\subsection{Impact of Environmental Risk on Financial Performance}

The relevance of environmental responsibility of corporations in general has become a popular topic of research over the last decades. This development has been motivated by environmental and social concerns, and most definitely by the potential impact of environmental risk on financial performance (Salama et al., 2011). The roots of environmental risk management lie in concepts such as corporate environmental performance (CEP) and ESG criteria. These concepts describe business activities in accordance with its stakeholders, namely, societies and the environment (Jin, 2018).

The relationship between a firm's environmental performance and its financial performance forms the basis for research on environmental risk since it implies that environmental hazards are reflected in current and past financial performance. It also gives incentives to assessing and managing environmental risks. We find five studies which investigate the impact of CEP on corporate financial performance (CFP). Except for the research conducted by Semenova and Hassel (2016), all articles focus on market risks of firms exhibiting different levels of environmental performance. The studies have similar methodological settings including the type of analyses and investigated dependent variable. Employing regression analyses, all studies test the systematic risk proxied through the market beta. While Salama et al. (2011) only test the systematic risk, all other studies test the total risk proxied through standard deviation. In addition, some studies consider the idiosyncratic risk (Sassen et al., 2016; Verheyden et al., 2016) or downside risk (Muhammad et al., 2015; Verheyden et al., 2016). Verheyden et al. (2016) stand out due to their complex measurement of risk-return characteristics not only on the stock level, but further on the portfolio level. The time periods in total range from 1994 to 2015 and include time overlaps that simplify the comparison of the empirical analyses.

The analysis of empirical results shows that the CEP is, in general, negatively associated with the market risk of companies. In particular, the total risk is lower for firms that have a higher CEP (Muhammad et al., 2015; Verheyden et al., 2016). The evidence presented in Sassen et al. (2016) for environmentally-sensitive industries (e.g., the engineering or transportation industries) also corroborates this finding. Regarding systematic risk, there is evidence to suggest that social and environmental engagement of firms lowers the systematic risk (Salama et al., 2011; Sassen et al., 2016). This finding is, however, not in line with Muhammad et al. (2015) whose results do not support this statement. Considering the impact of firms' environmental responsibility on downside risks, Muhammad et al. (2015) and Verheyden et al. (2016) show that CEP and ESG screenings decrease downside risk for both individual stock and portfolio levels. Two studies document opposing evidence for idiosyncratic risk. While Sassen et al. (2016) find that environmental performance decreases the firm's idiosyncratic risk, Verheyden et al. (2016) report slightly increased idiosyncratic risks for ESG screened portfolios, despite the fact that they both consider ESG ratings as a choice of CEP proxy. The main difference between their research design is the study period, from 2002 to 2014 for Sassen et al. (2016) and from 2010 to 2015 for

Journal of Economic Surveys (2021) Vol. 00, No. 00, pp. 1-27

(C) 2021 The Authors. Journal of Economic Surveys published by John Wiley \& Sons Ltd 
Verheyden et al. (2016), as well as the use of either the ESG-rated individual stock level or ESG-rated portfolio level. The increased idiosyncratic portfolio-level risk can be balanced by increased returns that overall positively impact risk-adjusted returns. This finding is especially important for the construction of environmental risk concerned hedge portfolios, as it highlights differences in the ESG-rated stock and portfolio characteristics.

Beyond its impact on market risk, the environmental performance of a firm is found to increase its market value. More specifically, news about environmental responsibility can increase the shareholder value, while negative information about a firm's environmental responsibility can negatively affect its shareholder value. There is evidence of rising relevance of shareholders' environmental concerns causing an increase in negative reactions toward harmful environmental behavior over time (Flammer, 2013). Regarding corporate environmental policies, the results reported in Fernando et al. (2017) show that both "toxic" and green firms have low institutional ownership, suggesting that shareholder value creation is associated with less environmental risk exposure, but does not increase with more environmental friendliness of firms.

The findings discussed above are further corroborated by research that directly investigates the impact of environmental hazards and environmental performance on financial downside (tail) risk. Ilhan et al. (2020a) use carbon emissions from the S\&P 500 companies disclosed by the Carbon Disclosure Project to measure the consequences of emission volatility on downside risk. The authors measure downside risk as the average tail loss of out-of-the-money put options because they capture the market expectation of jump risks. Their results show that an increase in the carbon emissions' standard deviation raises the tail risk standard deviation by $13 \%$ drawing a positive relationship between carbon emissions and tail risk. Moreover, the tail risk of carbon-intensive firms increased after the 2015 Paris Climate Agreement, which implies that regulations and technology connected with climate change influence financial risk.

Nguyen (2018) and Huang et al. (2018) investigate the effect of environmental hazards on financial risk characteristics, more specifically the volatility of earnings and cash flows measured by standard deviation of probability of loss and pretax income, respectively. These studies show that companies exposed to environmental or carbon emission hazards carry higher financial risk. Firms with high climate risk indices exhibit lower and more volatile earnings and cash flows (Huang et al., 2018), while firms with high carbon emissions are exposed to an increased probability of loss (Nguyen, 2018). In addition, Addoum et al. (2019) provide evidence that earnings are significantly affected by environmental hazards. Using U.S. firms and their locations to investigate how the exposure to temperatures over a 26-year period, they find that extreme temperatures affected the earnings per share of $40 \%$ of sample firms. However, temperature shocks do not significantly impact sales and productivity, even for industries that are considered to be heat-sensitive. This finding contradicts Nikolaou et al. (2015) who report strong effects of physical hazards on economic performance due to significantly increased costs. Both studies note that the extent of financial damage depends on the specific industry. Severe weather events also impact financing choices, as businesses in such regions hold more cash, less short-term and more longterm debt (Huang et al., 2018). These findings thus highlight the necessity of firms and financial services industry to account for environmental hazards regarding acute and chronic climate change events such as heat, drought, and other severe weather events.

Another stream of studies examines the impact of environmental risks on the cost of capital, as investors and lenders may mirror their perceived increased financial risk. The financial industry can thereby play a key role in incentivizing environmental responsibility and engagement of companies. Chava (2014) analyzes how environmental hazards impact the cost of equity and debt. The exposure to specific environmental hazards is estimated by three concerns, namely, exposure to excessive waste, emissions of toxic chemicals, and direct and indirect generation of revenues from fossil fuel products. The cost of equity is estimated by expected returns of stocks and the cost of debt is measured by bank loan spreads. The study documents an increased cost of equity as well as a higher interest rate on bank loans for firms with exposure to environmental hazards. This implies that firms with environmental

Journal of Economic Surveys (2021) Vol. 00, No. 00, pp. 1-27

(C) 2021 The Authors. Journal of Economic Surveys published by John Wiley \& Sons Ltd 
concerns carry specific risks from the investors' perspective and that default risk is not a simple function of higher interest rates. Other studies (Sharfman and Fernando, 2008; Kim et al., 2015; Jung et al., 2018) confirm the findings on cost of equity and show the positive association with carbon intensity as a proxy for carbon risk. This again pronounces the increased total risk of firms for which investors require higher compensation.

Finally, Kim et al. (2015) and Sharfman and Fernando (2008) outline the importance of environmental risk management, as it decreases the cost of capital. They conclude that the environmental-economic performance does improve through both better resource utilization and the engagement in environmental risk management. The only partially contradictory result is offered by Delis et al. (2020) who report no significant differences between loan spreads of fossil fuel firms and nonfossil fuel firms until 2015. However, this study's dependent variable differs, as it distinguishes firms with fossil fuel reserves from firms without reserves which nonetheless may greatly use fossil fuels.

Two studies are pronouncing the environmental risk of the industry as a contingency for the CEPCFP relationship at the company level. Semenova and Hassel (2016) test the effect of environmental management and environmental risk policies (primarily reporting efforts) on the market value in industries with low or high environmental risk. The authors find that the effect itself and its strength differ for the various industries. Environmental management and environmental policy exhibit a stronger (positive) effect on market values when the environmental risk of the industry is low. This raises the question of whether risk management is attributed higher importance than the risk itself. Kim et al. (2015) argue that the association between environmental risk and firm-level cost of equity is stronger for industries with low greenhouse gas emissions since firms from the sector are just as much exposed to regulatory risk as companies from carbon-intensive sectors. The directive effect of industry membership is important to investors in decision making and assessing not only climate risks at the firm but also industry levels.

The outlined research above provides evidence that firms with environmental responsibility and higher environmental performance exhibit lower market risk characteristics. It therefore pronounces the dependency of a company's financial risk on environmental concerns and its engagement in environmental responsibility. Moreover, studies directly consider environmental risk and its impact on financial performance, especially corporate earnings and cost of capital. The outcomes confirm findings on CEP contributing to the overall conclusion that environmental risks are negatively associated with financial performance. Environmental hazards pose a significant financial risk to companies and the financial sector, but at the same time provide incentives to improve financial performance metrics.

\subsection{Insight into Current Practices and Investors' Views}

As mentioned previously, enhanced financial performance characteristics of firms with lower environmental risk or an improved environmental risk management outline the need for the integration of environmental risk assessment in risk management processes. In particular, the cost of capital as a key element of capital budgeting is also driven by investors and lenders of the finance sector. It thus gives an indication of current practices in the banking sector and how investors potentially screen out stocks with environmental concerns implying lower institutional ownership and higher expected equity returns (Chava, 2014).

In this regard, several studies have conducted interviews, content, or literature analyses to find evidence for and information about current assessment of environmental risks in the financial sector. Those surveys are specifically relevant to current research because environmental risk management practices are difficult to derive from other empirical methods (Krueger et al., 2020).

Analyses on the financial sector come to ambiguous results highlighting the role of analysts and investors as individual decision makers. Providing negative conclusions on the question of current assessment, Campbell and Slack (2011) state that none of the 19 interviewed analysts considers

Journal of Economic Surveys (2021) Vol. 00, No. 00, pp. 1-27

(C) 2021 The Authors. Journal of Economic Surveys published by John Wiley \& Sons Ltd 
environmental risks within the risk assessment decision-making process. In addition, an analysis of the 2012 and 2015 Climate Risk Disclosure Survey of U.S. insurers indicates that most insurance companies do not account for environmental risk resulting from climate change in their main operations. The 2012 survey reports that $11 \%$ of insurance companies adapt climate risk assessment versus $39 \%$ in 2015 (Thistlethwaite and Wood, 2018). Somewhat negative feedback is reported by Weber et al. (2008) who received completed questionnaires from 50 of 205 European banks and find that more than $80 \%$ of the sample banks integrate environmental risks into the credit risk management process. Rather positive outcomes are presented by (Krueger et al., 2020) who conclude from their interviews that only $7 \%$ of 439 analysts have shown no efforts to account for climate risks within the last five years. At the firm level, Weber (2012) analyzes the social responsibility reports of nine Canadian banks and finds that all banks systematically integrate environmental risks into their credit management, but do not publish further information about the financial risk induced by environmental hazards.

Over time, the collected studies suggest progress in environmental risk assessment driven by increasing relevance of climate change and environmental concerns of firms. For the insurance sector, Thistlethwaite and Wood (2018) confirm an increase in assessment from 11\% to 39\% in only four years (2012-2015). Delis et al. (2020) report evidence that investors increasingly considered the climate policy risk of fossil fuel firms in the cost of borrowing from 2015 onward (year of the Paris Agreement), even though the increase is not of significant economic relevance. A similar conclusion is reached by the comparison of results reported in Campbell and Slack (2011) and Krueger et al. (2020) since the conducted interviews resemble each other closely, specifically on the subjects of qualitative outcomes. ${ }^{6}$ The studies reveal an increase from no assessment approaches at all in 2011 to $93 \%$ in 2018. However, it is striking that over $21 \%$ of the interview partners of Krueger et al. (2020) state that they started assessing environmental risks over 10 years ago which contradicts the qualitative findings of Campbell and Slack (2011).

Further evidence from these studies also portrays investors' perception toward environmental risk and its integration into the risk management process. Campbell and Slack (2011) find that environmental statements of banks generally remained unread and were considered the most immaterial section of annual reports. This is in line with some analysts' perception that environmental risk is not associated with a bank's risk at all. Some analysts regard the relevance of environmental reporting to potentially increase due to clients' concerns and valuation, but they screen out the potential materiality of environmental risk to be important for banks in general. Analysts did not find firms' environmental exposures to affect portfolios or forecasts, and environmental risk management to be important for risk assessment. In contrast, Solomon et al. (2011) report that investors see direct implications of climate change in that it represents a material risk. Krueger et al. (2020) confirm this outcome through interviews, which is in accordance with increasing awareness of investors toward environmental developments and climate change over the last decade. Accordingly, investors find environmental risks to have financial implications for portfolios and the corresponding portfolio firms. Most investors also report that climate risks have already begun to materialize and around $10-25 \%$ of them believe that the risk of assets becoming stranded for different electricity industry companies is "very high" (Krueger et al., 2020). Even though banks perceive risk to already materialize today, they expect the overall risk pricing to be overvalued.

Provided that banks assess environmental risk, it is not genuinely incorporated in all phases of risk management processes. Weber et al. (2008) address the incorporation into the credit risk management of banks and note that environmental risks are mostly considered in the risk identification phase (rating phase), but are less considered in risk evaluation and risk controlling.

Environmental risks are less likely to be considered in the process steps of costing and pricing. This shows a lack in systematic and quantitative incorporation throughout the entire risk management process. Krueger et al. (2020) further address tools used to identify and evaluate climate risks. In a broader view, banks take various approaches to cover climate risk management in the investment process, including carbon footprint analyses of portfolio firms and reduction of portfolio footprint as well as analyses and

Journal of Economic Surveys (2021) Vol. 00, No. 00, pp. 1-27

(C) 2021 The Authors. Journal of Economic Surveys published by John Wiley \& Sons Ltd 
reduction of stranded asset risk. Still, the two mostly used approaches, analyses of carbon footprints and stranded asset risks, have been employed by less than $40 \%$ of interviewed investors.

Other approaches are portfolio diversification, ESG and ESG rating integration, firm valuation models, and climate risk hedging. In order to directly assess potential impacts of climate risk on portfolios, investors rely on carbon footprint measurements, return impact measurements of climate risk, scenario analyses, and stress tests considering climate scenarios. The data used to assess the carbon footprint of portfolio firms is derived from corporate disclosures (self-collected), private reporting channels, the MSCI ESG database, or the Carbon Disclosure Project database (Solomon et al., 2011; Krueger et al., 2020). Further relevant data about greenhouse gas emissions is disclosed by Trucost or the South Pole Group (Andersson et al., 2016a).

Regarding public disclosures in 2011, investors state that, due to a lack in public corporate disclosures, they heavily rely on the private reporting channels of companies to receive relevant data about environmental concerns (Solomon et al., 2011). Even though policies regarding the disclosure commitment of firms were introduced and improved access to relevant environmental data since 2011, investors still report lacks in environmental public disclosure. They equally criticize the current level of mandatory disclosure and call for standardized and more precise quantitative information on firm climate risk (Ilhan et al., 2020a).

Eccles and Krzus (2018) examine how companies can meet the recommendations of the Task Force on Climate-related Financial Disclosures (TCFD) in order to make more comprehensive data available to investors. They analyze financial and voluntary reports of three oil and gas companies and find that most sophisticated environmental disclosure is found within the voluntary sustainability reports. Only few companies voluntarily published data from scenario analyses, as most companies worry that these analyses are perceived as forecasts by investors and could therefore negatively impact the companies. ${ }^{7}$ Eccles and Krzus (2018) highly suggest the compulsory integration of comprehensive environment- and sustainability-related data into financial reports to increase the quality of disclosures. In the knowledge of the disclosure gap, $60 \%$ of investors disclose or plan to disclose the overall portfolio carbon footprint (Ilhan et al., 2020a). Due to this poor disclosure, food stock prices are found to underreact to climaterelated risks such as droughts and are thus mispriced by the markets (Hong et al., 2019). For their part, Alok et al. (2020) investigate the potential overreaction of professional money managers to climatic disasters and find that investors misestimate climate risks and hold underweight positions in stocks located in disaster zones. Furthermore, this misperception of disaster-driven financial impacts decreases over time and is not related to any information advantages. Indeed, the underweighting of stocks located in climate disaster zones is refuted by the positive risk-adjusted returns of a portfolio that goes long in the most underweight stocks and short in the least underweight stocks.

Overall, current practices of environmental risk assessment give a mixed picture, ranging from no recognition of financial impacts of environmental risks in 2011 to advanced knowledge about the urgency to address climate risks in financial institutions in 2018. This clearly shows a development and moreover an increase in awareness and willingness to assess climate-related financial risk. Although most investors care about climate-related financial risk today, they face difficulties even with basic approaches such as carbon footprint analyses. The current challenges that remain to be overcome include disclosures of firm data, suitable risk assessment, and pricing instruments. Furthermore, characteristics of climate risks are needed to better understand the impact of environmental hazards on financial risk of firms and portfolios.

\subsection{Assessment Approaches}

As reported by Krueger et al. (2020), research addressing general risk management approaches mainly focuses on portfolio strategies (hedging, diversification) and risk measurement methods (carbon footprint, stranded assets, ESG rating, and firm valuation).

Journal of Economic Surveys (2021) Vol. 00, No. 00, pp. 1-27

(C) 2021 The Authors. Journal of Economic Surveys published by John Wiley \& Sons Ltd 
Regarding risk measurement methods and specifically the carbon footprint, Görgen et al. (2019) construct measures of carbon risk. The authors use four ESG databases to construct the "Brown-GreenScore" as an advanced approach to carbon risk. The Brown-Green-Score includes three indicators describing a firm's sensitivity to carbon risk (policy). This score is used to compute the "Brown-MinusGreen" portfolio that reflects the global market carbon risk. The "carbon beta" of a firm describes the firm's sensitivity to the global market carbon risk. Moreover, Görgen et al. (2019) calculated the carbon beta for both countries and industries. While there is a wide range of negative to positive sensitivity of various industries, energy, basic materials, and utilities industries exhibit the highest carbon risk sensitivities. The authors also highlight the impact of carbon risk on financial sector, with a high sensitivity depending on the carbon beta of the country. The carbon beta serves as a measure for firms, investors, and analysts to further understanding of specific carbon risk sensitivity.

Other studies combine carbon footprint measurement and hedging strategies to alleviate financial impacts of environmental hazards on portfolios. The modification of risk indices allows one to form index-tracking portfolios where the invested capital is protected against future negative events associated with climate change. Andersson et al. (2016b) and De Jong and Nguyen (2016) construct measures of low carbon intensity to foster portfolio decarbonization. These low-carbon indices modify the weighting of index components that exhibit high carbon intensity. The carbon intensity for the portfolios is defined by carbon footprints extracted from the MSCI ESG database (originally collected by the Carbon Disclosure Project). The outcomes of the studies show that the low-carbon index-tracking portfolios achieve a reduction in carbon emissions of 50-60\%. Both studies find no difference in the risk-adjusted return between their low-carbon portfolios and a benchmark portfolio.

For their part, Engle et al. (2020) consider the possibility of carbon emissions pricing and report an outperformance of the low-carbon portfolio compared to its benchmark. However, they do not construct an index tracking portfolio but an equity portfolio that overweighs stocks that positively react to climate change news. Relying on the assumption that low-carbon stock price increases when news about growing climate risk are announced, they do the portfolio sorting and weighting of components with respect to ESG scores from MSCI and Sustainalytics. The study uses two climate change indices which are derived from Wall Street Journal climate change and Crimson Hexagon negative climate change news articles. The portfolio can successfully hedge climate change news out-of-sample, whereby the portfolio using Sustainalytics outperforms the one using MSCI data. Thus, the performance of a hedge portfolio would depend on the adequate measure of environmental performance.

Barnett et al. (2020) introduce a theoretical framework to assess the social cost of carbon under uncertainty. They employ a dynamic stochastic equilibrium model that considers uncertainties from climate and economic modeling. Climate-related uncertainty concerns the transmission mechanism of human activity onto climate. Economic uncertainty results from the impact of uncertain climate damages on human welfare. Accounting for both sources of uncertainty, Barnett et al. (2020) find a substantial increase in the social cost of carbon. Bansal et al. (2016) also make use of the social cost of carbon in order to measure uncertainty induced by climate change. Testing U.S. equity portfolios, the study finds negative elasticity to temperature shifts and thus argues that the social cost of carbon represents present negative impacts on economic growth and equity valuations.

Georgopoulou et al. (2015) propose a methodological framework as well as a tool called "CLIMARISK" to quantitatively assess climate risks, and test their tool for a Greek bank. Interestingly, as it might potentially affect banks, D'Orazio and Popoyan (2019) address prudential approaches and regulation to incentivize banks in decarbonization including policies that reduce risks resulting from climate change and other environmental hazards. The so-called "green supporting factors" is a measure to foster lending to green sectors. This factor can be combined with adjustments in the minimum capital adequacy requirement of banks. These measures together can enhance investment in green sectors, as they are perceived less-risky (or derisking) assets and thus receive lower capital requirements. Similar to the green supporting factor, the "brown penalizing factor" works quite oppositely, requiring more capital reserves

Journal of Economic Surveys (2021) Vol. 00, No. 00, pp. 1-27

(C) 2021 The Authors. Journal of Economic Surveys published by John Wiley \& Sons Ltd 
for assets from carbon-intensive industries. This policy can furthermore cover banks, as the capital can account for more losses in case of a carbon bubble or stranded assets.

Other regulations, such as large exposure limits (e.g., credit limits) and the sectoral leverage ratio, can also contribute to decreasing financial risk. Exposure limits for banks will restrict the maximum amount of losses resulting from counterparty failure which is one of the potential financial risks induced by climate change. The sectoral leverage ratio restricts overleveraged asset positions of specific sectors and can also decrease exposure to climate risks (D’Orazio and Popoyan, 2019).

In summary, the development of climate risk measures can be relevant to investors and analysts as they see challenges in the assessment of environmental risks. Carbon risk measures such as the carbon beta can be considered in analysts' forecasts, investment and portfolio allocation decisions. However, research on this topic is still scarce and needs to be advanced along with the assessment of other, noncarbon and nonpolicy related, hazards as well as quantitative and financial analyses.

\section{Looking to the Future}

Emerging debates about climate change, policy measures on environmental disclosure, and rising awareness of institutional investors regarding environmental risks have enhanced research on the financial aspects of climate change within the last decade. The results of our systematic literature review thus enable the discussions about the current state of research and challenges of actual approaches for environmental risk assessment as well as the potential aspects that need to be addressed in the future.

A series of fundamental research addresses not only positive financial implications of CEP, but also their negative financial impacts for companies if they are exposed to environmental risks. Even though most research does assess market risk, the combination of environmental concerns (instead of environmental engagement) and financial risk is rarely investigated. Additional studies focusing on the characteristics of climate-related financial risk are obviously required in order to adequately estimate and assess financial consequences of environmental hazards. Future research can also be extended to directly examine the links between environmental concerns and financial risk. Bansal et al. (2016) already started to account for that by investigating the impact of temperature risk on risk premium in equity markets and its impact on equity price elasticity. Moreover, the distribution of returns can be further investigated regarding not only fat tails but also the skewness of distribution. Another intriguing question is the time horizon of when financial risk of environmental hazards will materialize, in the spirit of Giglio et al. (2015)'s study which investigates the impact of physical climate change risk on discount rate of real estate for the long run. Note that current research can hardly address materialization because it also depends on future developments of political and economic reaction to climate change (Bank of England, 2018; $2^{\circ}$ Investing Initiative, 2015).

The literature on current practices of environmental risk management exclusively elaborates quantitative and qualitative interviews. It shows the development from a minor, dispensable role a decade ago to the recognition of relevance and engagement among investors and analysts in the most recent interview conducted in 2018. However, there is a lack of studies aiming at directly identifying and evaluating concepts of assessment, tools, and the monitoring process of climate-related risks in financial institutions. The main reason is that current approaches depend not only on banks' and individual investors' perception of climate risk, but also on the level of regulation and requirements for financial institutions in terms of assessment and disclosure of financial risks related to climate change.

It is equally important to acknowledge that research on environmental risk assessment remains scarce and inconsistent with only few relevant qualitative studies. This aspect of research generally needs to be addressed further. Quantitative studies are particularly needed in order to estimate not only carbon emissions and intensities, but also physical and transition risk measures. For example, carbon intensity has to account for different levels of policy risk across countries and sectors, technology advancement,

Journal of Economic Surveys (2021) Vol. 00, No. 00, pp. 1-27

(C) 2021 The Authors. Journal of Economic Surveys published by John Wiley \& Sons Ltd 
and profit margins. These factors capture more specifically the sensitivity to legislation and policy actions. In addition, carbon emissions data are in their origin backward-looking and fails to display the current and future development and alignment of financial and nonfinancial firms. A forward-looking measure such as the assessment of stranded assets and stress testing has not been considered in the extracted studies of our literature review. Complementary to transitional risk hazards, physical climate change hazards can harm firms' operating and financial performance and pose a severe financial risk to banks. Physical risks of climate change have not been measured at the firm level but need to be considered through the geographic location of firms in disaster zones.

Key open questions remain especially with respect to the estimation and accessibility of environmental risk-related data which has not been directly addressed within the three topics due to missing discussions in research. One reason is the magnitude of climate change that is inconceivable and therefore difficult to estimate or model. This includes, for example, natural disaster probability modeling, water resources, and pollution (G20 Green Finance Study Group, 2017). Publicly available environmental data set the basis for all further research including the assessment of financial risk and poses a limitation toward the financial sector, as it impairs investors in addressing and pricing environment-driven financial risk. Besides, research must investigate how data on environmental concerns of companies can be disclosed more proficiently and standardized to derive quantitative statements from it (TCFD, 2017), and what quantitative statements about environmental hazards can impact investment decisions from a risk perspective. Both aspects require that there is a comprehensive understanding of scientific environmental data, and in the meanwhile banks and firms are able to define the economic meaning thereof.

Noteworthily, additional profound and topical research by institutions or initiatives (e.g., Bank of England, Mercer Consulting or the G20 Green Finance Study Group) also offer practical connections to current practices in the financial sector, illustrating the current state of risk assessment approaches and tools implemented (G20 Green Finance Study Group, 2017).

\section{Conclusion}

The aim of this study was to thematically discuss environmental risk management in the financial sector. We particularly examine what impact environmental risks have on firms' financial performance and exposure to financial risk, as well as what approaches are taken to assess these environmental risks.

Besides a theoretical background that contributes to solid understanding and delimitation of environmental risks, the main part of the study provides a broad analysis of the state-of-the-art research on environmental risks and their assessment in the financial sector. A systematic literature review identified a total of 38 relevant articles which are classified into three categories: (i) the impact of environmental concerns on financial performance; (ii) the current state of environmental risk management practices in the financial sector; and (iii) measures to assess those risks within financial institutions. Finally, we discuss the results on environmental risk management, focus on current challenges, and put forward potential alleys of further research.

The procedure of the systematic literature review in this work is to be reflected critically. By restricting the research to three databases and the exclusive use of English search terms and results, a holistic nature of the investigation cannot be guaranteed. By formulating selection criteria and limiting them to ranked journals, further filtering of the results also eliminated potential research. In order to achieve a scope of the study as holistic as possible, a snowball principle research was carried out in addition to the systematic literature review. While employing both research processes to select the final set of suitable and relevant articles, a subjective assessment of the journal articles cannot be ruled out. Moreover, the focus on peerreviewed studies may result in a publication bias of addressing only confirmatory results and neglecting of null or nonconfirmatory findings. 
Given the speed at which environmental risks have become an important topic, our present research has examined and considered environmental risk and especially its assessment fragmentarily. It is recognizable that research on environmental risk assessment is yet to commence, as the necessity of this subject continuously emerges. This, at the same time, poses opportunities for further research which we suggested in Section 5.

\section{Acknowledgments}

We thank Les Oxley (the editor), an anonymous reviewer, and Sebastian Utz for their helpful comments on an earlier version of this study. Part of the work has been conducted during Thomas Walther's research time as an Assistant Professor at the Institute for Operations Research and Computational Finance, School of Finance, University of St. Gallen. This publication is part of SCCER CREST (Swiss Competence Center for Energy Research), which is supported by Innosuisse (Swiss Innovation Agency). Thomas Walther is grateful for the funding received for conducting this research.

\section{Conflict of Interest}

The authors do not have any conflict of interest to disclose.

\section{Data Availability}

Data sharing is not applicable to this paper as no new data were created or analyzed in this study.

\section{Notes}

1. For example, Breitenstein et al. (2020) analyze the impact on the German coal industry of the governmental decision to phase-out coal.

2. The earliest study we find is Dixon and Coulson (1995), who state that the banking sector "have shown little interest in the environmental posture of organizations [..., but] there are signs that this is beginning to change." Later studies until 2007 comprise the analysis of the performance of ecoefficient funds (Derwall et al., 2005; Hoti et al., 2007), corporate governance-related issues (Cowton and Thompson, 2000; Thompson and Cowton, 2004), and research on the linkage between financial and environmental performance (King and Lenox, 2001).

3. The VHB JOURQUAL 3.0 ranking was conducted in 2012. The webpage states that the ranking does have a correlation of 0.66 and 0.70 with the British Academic Journal Quality Guide and Scimago Journal Rank, respectively. See https://vhbonline.org/vhb4you/vhb-jourqual/vhb-jourqual-3 (accessed 5 February 2020).

4. The result of the systematic literature research depends heavily on the keywords used, the search strings formulated from them, and the databases employed. This becomes clear when looking at search results per database in Table A.2. While a total of 45 relevant articles could be found via EBSCOhost, the identical searches at Emerald Insight and ScienceDirect provided only 6 and 13 significant publications, respectively.

5. The study by Hong et al. (2019) is published in a journal outside of this ranking, but nonetheless comes with an 2018 impact factor of 1.949.

6. Both interviews are conducted with analysts and investors, but differ in the number of interview partners (19 vs. 439) and structure of the interviews (unstructured and qualitatively vs. structured and quantitatively).

7. See also Düsterhöft et al. (2020) who show that energy utilities do not disclose climate-related risks at all in the risk section of the note to the annual financial reports for a sample from 2007 to 2017.

Journal of Economic Surveys (2021) Vol. 00, No. 00, pp. 1-27

(C) 2021 The Authors. Journal of Economic Surveys published by John Wiley \& Sons Ltd 


\section{References}

$2^{\circ}$ Investing Initiative (2015) Financial risk and the transition to a low-carbon economy. Tech. Rep., $2^{\circ}$ Investing Initiative. Available at: http://unepinquiry.org/wp-content/uploads/2015/10/2dii_risk_transition_lowcarbon_workingpaper_jul2015.pdf. Accessed November 16, 2020.

Addoum, J.M., Ng, D.T. and Ortiz-Bobea, A. (2019) Temperature shocks and industry earnings news. Available at: https://www.ssrn.com/abstract=3480695. Accessed November 16, 2020.

Addoum, J.M., Ng, D.T. and Ortiz-Bobea, A. (2020) Temperature shocks and establishment sales. Review of Financial Studies 33: 1331-1366.

Alok, S., Kumar, N. and Wermers, R. (2020) Do fund managers misestimate climatic disaster risk. Review of Financial Studies 33: 1146-1183.

Andersson, M., Bolton, P. and Samama, F. (2016a) Governance and climate change: a success story in mobilizing investor support for corporate responses to climate change. Journal of Applied Corporate Finance 28: 29-33.

Andersson, M., Bolton, P. and Samama, F. (2016b) Hedging climate risk. Financial Analysts Journal 72: 1332.

Bank of England (2015) The impact of climate change on the UK insurance sector. Tech. Rep., Bank of England. Available at: https://www.bankofengland.co.uk/-/media/boe/files/prudential-regulation/policystatement/2019/ps1119.pdf. Accessed November 16, 2020.

Bank of England (2018) Enhancing banks' and insurers' approaches to managing the financial risks from climate change. Tech. Rep., Bank of England. Available at: https://www.bankofengland. co.uk/-/media/boe/files/prudential-regulation/policy-statement/2019/ps1119.pdf?la=en\&hash= CD95D958ECD437140A4C7CF94337DAFD8AD962DE. Accessed November 16, 2020.

Bank of England and Banque de France (2019) Open letter from the Governor of Bank of England Mark Carney, Governor of Banque de France François Villeroy de Galhau and Chair of the Network for Greening the Financial Services Frank Elderson. Available at: http://www.bankofengland.co.uk/news/ 2019/april/open-letter-on-climate-related-financial-risks. Accessed November 16, 2020.

Bansal, R., Kiku, D. and Ochoa, M. (2016) Price of long-run temperature shifts in capital markets. Tech. Rep. 22529, National Bureau of Economic Research. Available at: http://www.nber.org/papers/w22529. Accessed November 16, 2020.

Barnett, M., Brock, W. and Hansen, L.P. (2020) Pricing uncertainty induced by climate change. Review of Financial Studies 33: 1024-1066.

Basel Committee on Banking Supervision (2020) Climate-related financial risks: a survey on current initiatives. Tech. Rep. April, Bank of International Settlements, Basel. Available at: https://www.bis.org/bcbs/publ/ d502.htm. Accessed November 16, 2020.

Batten, S., Sowerbutts, R. and Tanaka, M. (2016) Let's talk about the weather: the impact of climate change on central banks. Tech. Rep. 603, Bank of England. Available at: https://ideas.repec.org/p/boe/boeewp/0603. html. Accessed November 16, 2020.

Battiston, S., Mandel, A., Monasterolo, I., Schütze, F. and Visentin, G. (2017) A climate stress-test of the financial system. Nature Climate Change 7: 283-288.

Boermans, M.A. and Galema, R. (2019) Are pension funds actively decarbonizing their portfolios? Ecological Economics 161: 50-60.

Braun, A., Utz, S. and Xu, J. (2019) Are insurance balance sheets carbon-neutral? Harnessing asset pricing for climate change policy. Geneva Papers on Risk and Insurance - Issues and Practice 44: 549-568.

Breitenstein, M., Anke, C.-P., Nguyen, D.K. and Walther, T. (2020) Stranded asset risk and political uncertainty: the impact of the coal phase-out on the german coal industry. Available at: https://www. ssrn.com/abstract=3604984. Accessed November 16, 2020.

Caldecott, B. and McDaniels, J. (2014) Financial dynamics of the environment risks, impacts, and barriers to resilience. Tech. Rep., The Inquiry into the Design of a Sustainable Financial System. Available at: https://www.smithschool.ox.ac.uk/research/sustainable-finance/publications/UNEP-SSEEWorking-Paper-Financial-Dynamics-of-the-Environment.pdf. Accessed November 16, 2020.

Cambridge Centre for Sustainable Finance (2016) Environmental risk analysis by financial institutions - a review of global practice. Tech. Rep., Cambridge Institute for Sustainability Leadership. 
Available at: http://unepinquiry.org/wp-content/uploads/2016/09/2_Environmental_Risk_Analysis_by_ Financial_Institutions.pdf. Accessed November 16, 2020.

Campbell, D. and Slack, R. (2011) Environmental disclosure and environmental risk: sceptical attitudes of UK sell-side bank analysts. British Accounting Review 43: 54-64.

Campiglio, E., Dafermos, Y., Monnin, P., Ryan-Collins, J., Schotten, G. and Tanaka, M. (2018) Climate change challenges for central banks and financial regulators. Nature Climate Change 8: 462-468.

Carbon Disclosure Project (2019) World's biggest companies face $\$ 1$ trillion in climate change risks. Available at: https://www.cdp.net/en/articles/media/worlds-biggest-companies-face-1-trillion-inclimate-change-risks. Accessed November 16, 2020.

Chava, S. (2014) Environmental externalities and cost of capital. Management Science 60: 2223-2247.

Cowton, C.J. and Thompson, P. (2000) Do codes make a difference? The case of bank lending and the environment. Journal of Business Ethics 24: 165-178.

De Jong, M. and Nguyen, A. (2016) Weathered for climate risk: a bond investment proposition. Financial Analysts Journal 72: 34-39.

Delis, M.D., de Greiff, K. and Ongena, S. (2020) Being Stranded with Fossil Fuel Reserves? Climate Policy Risk and the Pricing of Bank Loans (April 21, 2019). Swiss Finance Institute Research Paper No. 18-10, Available at: https://doi.org/10.2139/ssrn.3125017. Accessed November 16, 2020.

Derwall, J., Guenster, N., Bauer, R. and Koedijk, K. (2005) The eco-efficiency premium puzzle. Journal of Financial Analysts 61: 51-63.

Dietz, S., Bowen, A., Dixon, C. and Gradwell, P. (2016) Climate value at risk of global financial assets. Nature Climate Change 6: 676-679.

Dixon, R. and Coulson, A.B. (1995) Environmental risk and management strategy: the implications for financial institutions. International Journal of Bank Marketing 13: 22-29.

D’Orazio, P. and Popoyan, L. (2019) Fostering green investments and tackling climate-related financial risks: which role for macroprudential policies? Ecological Economics 160: 25-37.

Düsterhöft, M., Schiemann, F. and Walther, T. (2020) Let's talk about risk! The firm value effect of risk disclosure for European energy utilities. Available at: https://papers.ssrn.com/sol3/papers.cfm?abstract_ id $=3692372$. Accessed November 16, 2020.

Eccles, R.G. and Krzus, M. (2018) Why companies should report financial risks from climate change. MITSloan Management Review, 59. Available at: https://sloanreview.mit.edu/article/why-companiesshould-report-financial-risks-from-climate-change/. Accessed November 16, 2020.

Engle, R.F., Giglio, S., Kelly, B., Lee, H. and Stroebel, J. (2020) Hedging climate change news. Review of Financial Studies 33: 1184-1216.

Fernando, C.S., Sharfman, M.P. and Uysal, V.B. (2017) Corporate environmental policy and shareholder value: following the smart money. Journal of Financial and Quantitative Analysis 52: 2023-2051.

Flammer, C. (2013) Corporate social responsibility and shareholder reaction: the environmental awareness of investors. Academy of Management Journal 56: 758-781.

G20 Green Finance Study Group (2017) G20 green finance synthesis report. Tech. Rep., G20 Green Finance Study Group. Available at: http://unepinquiry.org/wp-content/uploads/2017/07/2017_GFSG_Synthesis_ Report_EN.pdf. Accessed November 16, 2020.

Gatzert, N. and Wesker, H. (2012) A comparative assessment of basel II/III and solvency II. Geneva Papers on Risk and Insurance - Issues and Practice 37: 539-570.

Georgopoulou, E., Mirasgedis, S., Sarafidis, Y., Hontou, V., Gakis, N., Lalas, D., Xenoyianni, F., Kakavoulis, N., Dimopoulos, D. and Zavras, V. (2015) A methodological framework and tool for assessing the climate change related risks in the banking sector. Journal of Environmental Planning and Management 58: 874897.

Giglio, S., Maggiori, M., Stroebel, J. and Weber, A. (2015) Climate change and long-run discount rates: evidence from real estate. Tech. Rep. 21767, National Bureau of Economic Research. Available at: http://www.nber.org/papers/w21767. Accessed November 16, 2020.

Görgen, M., Jacob, A., Nerlinger, M., Riordan, R., Rohleder, M. and Wilkens, M. (2019) Carbon risk. Available at: http://www.ssrn.com/abstract=2930897. Accessed November 16, 2020.

Hong, H., Li, F.W. and Xu, J. (2019) Climate risks and market efficiency. Journal of Econometrics 208: 265281.

Journal of Economic Surveys (2021) Vol. 00, No. 00, pp. 1-27

(c) 2021 The Authors. Journal of Economic Surveys published by John Wiley \& Sons Ltd 
Hoti, S., McAleer, M. and Pauwels, L.L. (2007) Measuring risk in environmental finance. Journal of Economic Surveys 21: 970-998.

Huang, H.H., Kerstein, J. and Wang, C. (2018) The impact of climate risk on firm performance and financing choices: an international comparison. Journal of International Business Studies 49: 633-656.

Ilhan, E., Krueger, P., Sautner, Z. and Starks, L.T. (2020a) Climate risk disclosure and institutional investors. Available at: https://www.ssrn.com/abstract=3437178. Accessed November 16, 2020.

Ilhan, E., Sautner, Z. and Vilkov, G. (2020b) Carbon tail risk. Review of Financial Studies, forthcoming https: //doi.org/10.1093/rfs/hhaa071. Accessed November 16, 2020.

Jin, I. (2018) Is ESG a systematic risk factor for US equity mutual funds? Journal of Sustainable Finance and Investment 8: 72-93.

Jung, J., Herbohn, K. and Clarkson, P. (2018) Carbon risk, carbon risk awareness and the cost of debt financing. Journal of Business Ethics 150: 1151-1171.

Kim, Y.B., An, H.T. and Kim, J.D. (2015) The effect of carbon risk on the cost of equity capital. Journal of Cleaner Production 93: 279-287.

King, A.A. and Lenox, M.J. (2001) Does It Really Pay to Be Green? An Empirical Study of Firm Environmental and Financial Performance: An Empirical Study of Firm Environmental and Financial Performance. Journal of Industrial Ecology 5: 105-116.

Krueger, P., Sautner, Z. and Starks, L.T. (2020) The importance of climate risks for institutional investors. Review of Financial Studies 33: 1067-1111.

Liston-Heyes, C. and Vazquez Brust, D.A. (2016) Environmental protection in environmentally reactive firms: lessons from corporate argentina. Journal of Business Ethics 135: 361-379.

Litterman, R. (2011) Pricing climate change risk appropriately. Financial Analysts Journal 67: 4-10.

Mercer Investment Consulting (2015) Investing in a time of climate change. Tech. Rep., Mercer Investment Consulting. Available at: http://www.mmc.com/content/dam/mmc-web/insights/publications/2019/apr/ FINAL_Investing-in-a-Time-of-Climate-Change-2019-Full-Report.pdf. Accessed November 16, 2020.

Muhammad, N., Scrimgeour, F., Reddy, K. and Abidin, S. (2015) The impact of corporate environmental performance on market risk: the Australian industry case. Journal of Business Ethics 132: 347 362.Available at: http://doi.org/10.1007/s10551-014-2324-3. Accessed November 16, 2020.

Muralikrishna, I.V. and Manickam, V. (2017) Environmental risk assessment. In Environmental Management (pp. 135-152). Oxford: Elsevier.

NGFS (2019) A call for action: climate change as a source of financial risk. Tech. Rep. Available at: https://www.banque-france.fr/sites/default/files/media/2019/04/17/ngfs_first_comprehensive_report__17042019_0.pdf. Accessed November 16, 2020.

Nguyen, J.H. (2018) Carbon risk and firm performance: evidence from a quasi-natural experiment. Australian Journal of Management 43: 65-90.

Nikolaou, I., Evangelinos, K. and Leal Filho, W. (2015) A system dynamic approach for exploring the effects of climate change risks on firms' economic performance. Journal of Cleaner Production 103: 499-506.

Salama, A., Anderson, K. and Toms, J.S. (2011) Does community and environmental responsibility affect firm risk? Evidence from UK panel data 1994-2006. Business Ethics 20: 192-204.

Sassen, R., Hinze, A.K. and Hardeck, I. (2016) Impact of ESG factors on firm risk in Europe. Journal of Business Economics 86: 867-904.

Semenova, N. and Hassel, L.G. (2016) The moderating effects of environmental risk of the industry on the relationship between corporate environmental and financial performance. Journal of Applied Accounting Research 17: 97-114.

Sharfman, M.P. and Fernando, C.S. (2008) Environmental risk management and the cost of capital. Strategic Management Journal 29: 569-592.

Smith, K. (2004) Environmental Hazards: Assessing Risk and Reducing Disaster (4th edn). London: Routledge.

Solomon, J.F., Solomon, A., Norton, S.D. and Joseph, N.L. (2011) Private climate change reporting: an emerging discourse of risk and opportunity? Accounting, Auditing and Accountability Journal 24: 11191148 .

Sustainable Finance Lab (2018) Central banks ignore climate risks at their peril. Available at: https: //sustainablefinancelab.nl/en/central-banks-ignore-climate-risks-at-their-peril/. Accessed November 16, 2020.

Journal of Economic Surveys (2021) Vol. 00, No. 00, pp. 1-27

(C) 2021 The Authors. Journal of Economic Surveys published by John Wiley \& Sons Ltd 
TCFD (2017) Final report: recommendations of the task force on climate-related financial disclosures. Tech. Rep., December, Financial Stability Board, Basel. Available at: https://www.fsb-tcfd.org/wp-content/ uploads/2017/06/FINAL-2017-TCFD-Report-11052018.pdf. Accessed November 16, 2020.

Thistlethwaite, J. and Wood, M.O. (2018) Insurance and climate change risk management: rescaling to look beyond the horizon. British Journal of Management 29: 279-298.

Thompson, P. and Cowton, C.J. (2004) Bringing the environment into bank lending: implications for environmental reporting. British Accounting Review 36: 197-218.

Tranfield, D., Denyer, D. and Smart, P. (2003) Towards a methodology for developing evidence-informed management knowledge by means of systematic review. British Journal of Management 14: 207-222.

Verheyden, T., Eccles, R.G. and Feiner, A. (2016) ESG for all? The impact of ESG screening on return, risk, and diversification. Journal of Applied Corporate Finance 28: 47-55.

Weber, O. (2012) Environmental credit risk management in banks and financial service institutions. Business Strategy and the Environment 21: 248-263.

Weber, O., Fenchel, M. and Scholz, R.W. (2008) Empirical analysis of the integration of environmental risks into the credit risk management process of European banks. Business Strategy and the Environment 17: 149-159.

\section{Appendix A}

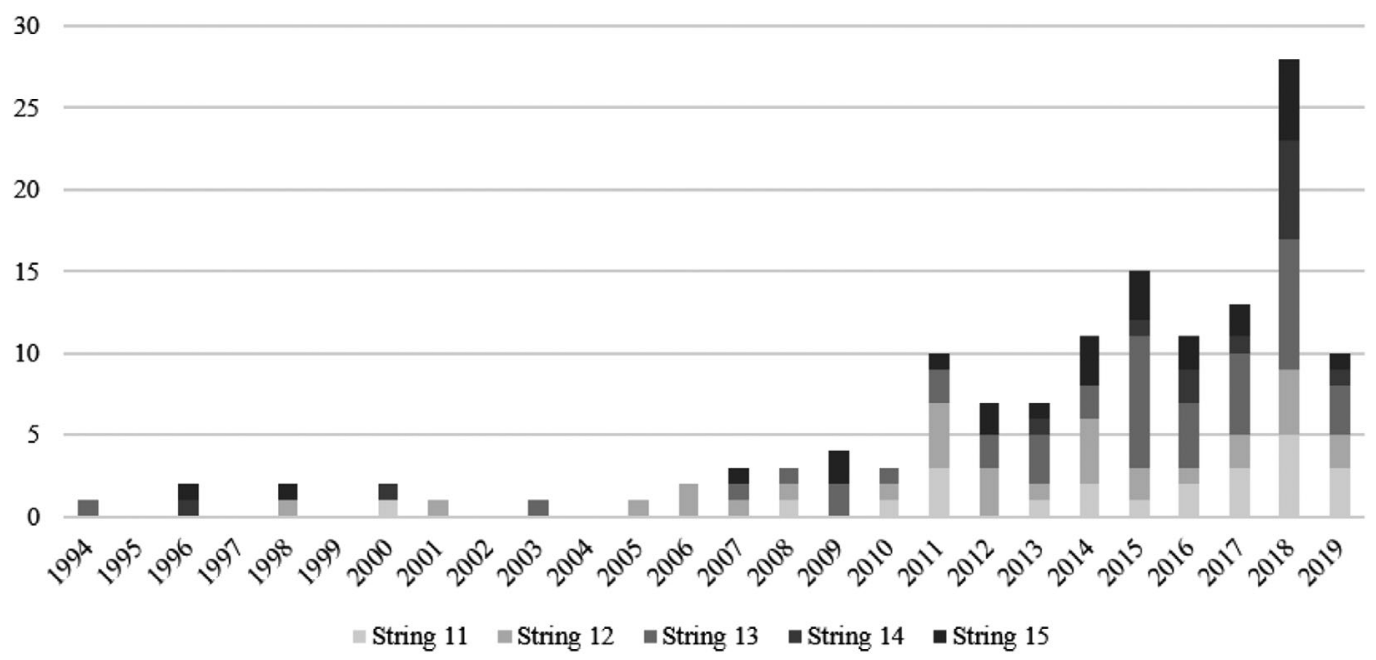

Figure A.1. Historic Classification of Search Results through ScienceDirect Database (Search Strings 11-15).

Table A.1. List of Results from the Systematic Literature Research.

\begin{tabular}{ccccccc}
\hline \hline No. & Authors (Year) & Title & Journal & Rating & Time span & \#Obs. \\
\hline 1 & Addoum et al. & Temperature Shocks and & Review of \\
(2020) & Establishment Sales & Atudies & 1990-2015 & 4,397 \\
& & & & & & \\
\end{tabular}

(Continued)

Journal of Economic Surveys (2021) Vol. 00, No. 00, pp. 1-27

() 2021 The Authors. Journal of Economic Surveys published by John Wiley \& Sons Ltd 
Table A.1. (Continued).

\begin{tabular}{|c|c|c|c|c|c|c|}
\hline No. & Authors (Year) & Title & Journal & Rating & Time span & \#Obs. \\
\hline 2 & $\begin{array}{l}\text { Alok et al. } \\
\quad(2020)\end{array}$ & $\begin{array}{l}\text { Do Fund Managers } \\
\text { Misestimate Climatic } \\
\text { Disaster Risk }\end{array}$ & $\begin{array}{l}\text { Review of } \\
\text { Financial } \\
\text { Studies }\end{array}$ & $\mathrm{A}+$ & 1995-2016 & 3,268 \\
\hline 3 & $\begin{array}{l}\text { Barnett et al. } \\
\quad(2020)\end{array}$ & $\begin{array}{l}\text { Pricing Uncertainty Induced } \\
\text { by Climate Change }\end{array}$ & $\begin{array}{l}\text { Review of } \\
\quad \text { Financial } \\
\text { Studies }\end{array}$ & $\mathrm{A}+$ & $N A$ & $N A$ \\
\hline 4 & $\begin{array}{l}\text { Delis et al. } \\
\quad(2020)\end{array}$ & $\begin{array}{l}\text { Being Stranded on the Carbon } \\
\text { Bubble? Climate Policy } \\
\text { Risk and the Pricing of } \\
\text { Bank Loans }\end{array}$ & Working Paper & & 2007-2016 & 72,742 \\
\hline 5 & $\begin{array}{l}\text { Engle } \text { et al. } \\
\quad(2020)\end{array}$ & $\begin{array}{l}\text { Hedging Climate Change } \\
\text { News }\end{array}$ & $\begin{array}{l}\text { Review of } \\
\text { Financial } \\
\text { Studies }\end{array}$ & $\mathrm{A}+$ & 2009-2016 & 796 \\
\hline 6 & $\begin{array}{r}\text { Ilhan et al. } \\
\text { (2020a) }\end{array}$ & $\begin{array}{l}\text { Climate Risk Disclosure and } \\
\text { Institutional Investors }\end{array}$ & Working Paper & & 2017-2018 & 439 \\
\hline 7 & $\begin{array}{r}\text { Ilhan et al. } \\
\quad(2020 \mathrm{~b})\end{array}$ & Carbon Tail Risk & $\begin{array}{l}\text { Review of } \\
\quad \text { Financial } \\
\text { Studies }\end{array}$ & $\mathrm{A}+$ & 2010-2017 & 3,206 \\
\hline 8 & $\begin{array}{l}\text { Krueger et al. } \\
\quad(2020)\end{array}$ & $\begin{array}{l}\text { The Importance of Climate } \\
\text { Risks for Institutional } \\
\text { Investors }\end{array}$ & $\begin{array}{l}\text { Review of } \\
\quad \text { Financial } \\
\text { Studies }\end{array}$ & $\mathrm{A}+$ & 2017-2018 & 439 \\
\hline 9 & $\begin{array}{l}\text { Addoum et al. } \\
\text { (2019) }\end{array}$ & $\begin{array}{l}\text { Temperature Shocks and } \\
\text { Industry Earnings News }\end{array}$ & Working Paper & & 1990-2015 & 8,584 \\
\hline 10 & $\begin{array}{l}\text { D’Orazio and } \\
\text { Popoyan } \\
(2019)\end{array}$ & $\begin{array}{l}\text { Fostering Green Investments } \\
\text { and Tackling } \\
\text { Climate-Related Financial } \\
\text { Risks: Which Role for } \\
\text { Macroprudential Policies? }\end{array}$ & $\begin{array}{l}\text { Ecological } \\
\text { Economics }\end{array}$ & B & $N A$ & $N A$ \\
\hline 11 & $\begin{array}{l}\text { Görgen et al. } \\
\quad \text { (2019) }\end{array}$ & Carbon Risk & Working Paper & & 2010-2016 & 39,537 \\
\hline 12 & $\begin{array}{l}\text { Hong et al. } \\
\quad \text { (2019) }\end{array}$ & $\begin{array}{l}\text { Climate Risks and Market } \\
\text { Efficiency }\end{array}$ & $\begin{array}{l}\text { Journal of } \\
\quad \text { Econometrics }\end{array}$ & IF 1.9 & 1985-2014 & $>910$ \\
\hline 13 & $\begin{array}{l}\text { Eccles and } \\
\text { Krzus (2018) }\end{array}$ & $\begin{array}{l}\text { Why Companies Should } \\
\text { Report Financial Risks } \\
\text { From Climate Change }\end{array}$ & $\begin{array}{l}\text { MIT Sloan } \\
\quad \text { Management } \\
\text { Review }\end{array}$ & $\mathrm{C}$ & $N A$ & $N A$ \\
\hline 14 & $\begin{array}{l}\text { Huang et al. } \\
\quad \text { (2018) }\end{array}$ & $\begin{array}{l}\text { The Impact of Climate Risk on } \\
\text { Firm Performance and } \\
\text { Financing Choices: an } \\
\text { International Comparison }\end{array}$ & $\begin{array}{l}\text { Journal of } \\
\text { International } \\
\text { Business } \\
\text { Studies }\end{array}$ & A & 1993-2012 & 353,906 \\
\hline 15 & $\begin{array}{l}\text { Jung et al. } \\
\text { (2018) }\end{array}$ & $\begin{array}{l}\text { Carbon Risk, Carbon Risk } \\
\text { Awareness and the Cost of } \\
\text { Debt Financing }\end{array}$ & $\begin{array}{l}\text { Journal of } \\
\quad \text { Business Ethics }\end{array}$ & B & 2009-2013 & 255 \\
\hline
\end{tabular}

(Continued) 
Table A.1. (Continued).

\begin{tabular}{|c|c|c|c|c|c|c|}
\hline No. & Authors (Year) & Title & Journal & Rating & Time span & \#Obs. \\
\hline 16 & Nguyen (2018) & $\begin{array}{l}\text { Carbon Risk and Firm } \\
\text { Performance: Evidence } \\
\text { From a Quasi-Natural } \\
\text { Experiment }\end{array}$ & $\begin{array}{l}\text { Australian } \\
\quad \text { Journal of } \\
\text { Management }\end{array}$ & $\mathrm{C}$ & 2000-2014 & 24,905 \\
\hline 17 & $\begin{array}{l}\text { Thistlethwaite } \\
\text { and Wood } \\
\text { (2018) }\end{array}$ & $\begin{array}{l}\text { Insurance and Climate Change } \\
\text { Risk Management: } \\
\text { Rescaling to Look Beyond } \\
\text { the Horizon }\end{array}$ & $\begin{array}{l}\text { British Journal of } \\
\text { Management }\end{array}$ & B & 2012,2015 & 178,183 \\
\hline 18 & $\begin{array}{l}\text { Fernando et al. } \\
\quad \text { (2017) }\end{array}$ & $\begin{array}{l}\text { Corporate Environmental } \\
\text { Policy and Shareholder } \\
\text { Value: Following the Smart } \\
\text { Money }\end{array}$ & $\begin{array}{l}\text { Journal of } \\
\text { Financial and } \\
\text { Quantitative } \\
\text { Analysis }\end{array}$ & A & 1996-2007 & 7,324 \\
\hline 19 & $\begin{array}{l}\text { Andersson et al. } \\
\quad \text { (2016a) }\end{array}$ & $\begin{array}{l}\text { Governance and Climate } \\
\text { Change: A Success Story in } \\
\text { Mobilizing Investor Support } \\
\text { for Corporate Responses to } \\
\text { Climate Change }\end{array}$ & $\begin{array}{l}\text { Journal of Applied } \\
\text { Corporate } \\
\text { Finance }\end{array}$ & $\mathrm{C}$ & $N A$ & $N A$ \\
\hline 20 & $\begin{array}{l}\text { Andersson et al. } \\
\quad(2016 \mathrm{~b})\end{array}$ & Hedging Climate Risk & $\begin{array}{l}\text { Financial Analysts } \\
\quad \text { Journal }\end{array}$ & B & 2014-2016 & $N A$ \\
\hline 21 & $\begin{array}{l}\text { Bansal et al. } \\
\quad \text { (2016) }\end{array}$ & $\begin{array}{l}\text { Price of Long-Run } \\
\text { Temperature Shifts in } \\
\text { Capital Markets }\end{array}$ & Working Paper & & 1934-2014 & 35 \\
\hline 22 & $\begin{array}{l}\text { De Jong and } \\
\text { Nguyen } \\
\text { (2016) }\end{array}$ & $\begin{array}{l}\text { Weathered for Climate Risk: A } \\
\text { Bond Investment } \\
\text { Proposition }\end{array}$ & $\begin{array}{l}\text { Financial Analysts } \\
\quad \text { Journal }\end{array}$ & B & 2011-2014 & $N A$ \\
\hline 23 & $\begin{array}{l}\text { Sassen et al. } \\
\quad \text { (2016) }\end{array}$ & $\begin{array}{l}\text { Impact of ESG Factors on } \\
\text { Firm Risk in Europe }\end{array}$ & $\begin{array}{l}\text { Journal of } \\
\text { Business } \\
\text { Economics }\end{array}$ & B & 2002-2014 & 8,752 \\
\hline 24 & $\begin{array}{l}\text { Semenova and } \\
\text { Hassel (2016) }\end{array}$ & $\begin{array}{l}\text { The Moderating Effects of } \\
\text { Environmental Risk of the } \\
\text { Industry on the Relationship } \\
\text { Between Corporate } \\
\text { Environmental and } \\
\text { Financial Performance }\end{array}$ & $\begin{array}{l}\text { Journal of Applied } \\
\quad \text { Accounting } \\
\quad \text { Research }\end{array}$ & $\mathrm{C}$ & 2003-2011 & 5,326 \\
\hline 25 & $\begin{array}{l}\text { Verheyden et al. } \\
\quad \text { (2016) }\end{array}$ & $\begin{array}{l}\text { ESG for All? The Impact of } \\
\text { ESG Screening on Return, } \\
\text { Risk, and Diversification }\end{array}$ & $\begin{array}{l}\text { Journal of Applied } \\
\text { Corporate } \\
\text { Finance }\end{array}$ & $\mathrm{C}$ & 2010-2015 & 2,512 \\
\hline 26 & $\begin{array}{l}\text { Georgopoulou } \\
\text { et al. (2015) }\end{array}$ & $\begin{array}{l}\text { A Methodological Framework } \\
\text { and Tool for Assessing the } \\
\text { Climate Change Related } \\
\text { Risks in the Banking Sector }\end{array}$ & $\begin{array}{l}\text { Journal of } \\
\text { Environmental } \\
\text { Planning and } \\
\text { Management }\end{array}$ & $\mathrm{C}$ & $N A$ & $N A$ \\
\hline 27 & $\begin{array}{l}\text { Kim et al. } \\
\quad \text { (2015) }\end{array}$ & $\begin{array}{l}\text { The Effect of Carbon Risk on } \\
\text { the Cost of Equity Capital }\end{array}$ & $\begin{array}{l}\text { Journal of } \\
\text { Cleaner } \\
\text { Production }\end{array}$ & B & 2007-2011 & 379 \\
\hline
\end{tabular}


Table A.1. (Continued).

\begin{tabular}{|c|c|c|c|c|c|c|}
\hline No. & Authors (Year) & Title & Journal & Rating & Time span & \#Obs. \\
\hline 28 & $\begin{array}{l}\text { Muhammad } \\
\text { et al. (2015) }\end{array}$ & $\begin{array}{l}\text { The Impact of Corporate } \\
\text { Environmental Performance } \\
\text { on Market Risk: The } \\
\text { Australian Industry Case }\end{array}$ & $\begin{array}{l}\text { Journal of } \\
\quad \text { Business Ethics }\end{array}$ & B & 2001-2010 & 760 \\
\hline 29 & $\begin{array}{l}\text { Nikolaou et al. } \\
\text { (2015) }\end{array}$ & $\begin{array}{l}\text { A System-Dynamic Approach } \\
\text { for Exploring the Effects of } \\
\text { Climate Change Risks on } \\
\text { Firms' Economic } \\
\text { Performance }\end{array}$ & $\begin{array}{l}\text { Journal of } \\
\quad \text { Cleaner } \\
\text { Production }\end{array}$ & B & $N A$ & $N A$ \\
\hline 30 & Chava (2014) & $\begin{array}{l}\text { Environmental Externalities } \\
\text { and Cost of Capital }\end{array}$ & $\begin{array}{l}\text { Management } \\
\text { Science }\end{array}$ & $\mathrm{A}+$ & 1992-2007 & 13,114 \\
\hline 31 & Flammer (2013) & $\begin{array}{l}\text { Corporate Social } \\
\text { Responsibility and } \\
\text { Shareholder Reaction: The } \\
\text { Environmental Awareness } \\
\text { of Investors }\end{array}$ & $\begin{array}{l}\text { Academy of } \\
\text { Management } \\
\text { Journal }\end{array}$ & $\mathrm{A}+$ & 1980-2009 & 117,156 \\
\hline 32 & Weber (2012) & $\begin{array}{l}\text { Environmental Credit Risk } \\
\text { Management in Banks and } \\
\text { Financial Service } \\
\text { Institutions }\end{array}$ & $\begin{array}{l}\text { Business Strategy } \\
\text { and the } \\
\text { Environment }\end{array}$ & B & 2006-2009 & 71 \\
\hline 33 & $\begin{array}{l}\text { Campbell and } \\
\text { Slack (2011) }\end{array}$ & $\begin{array}{l}\text { Environmental disclosure and } \\
\text { environmental risk: } \\
\text { Sceptical attitudes of UK } \\
\text { sell-side bank analysts }\end{array}$ & $\begin{array}{l}\text { British } \\
\quad \text { Accounting } \\
\quad \text { Review }\end{array}$ & $\mathrm{C}$ & 2004-2006 & 19 \\
\hline 34 & $\begin{array}{l}\text { Litterman } \\
\quad(2011)\end{array}$ & $\begin{array}{l}\text { Pricing Climate Change Risk } \\
\text { Appropriately }\end{array}$ & $\begin{array}{l}\text { Financial Analysts } \\
\quad \text { Journal }\end{array}$ & B & $N A$ & $N A$ \\
\hline 35 & $\begin{array}{l}\text { Salama et al. } \\
\quad \text { (2011) }\end{array}$ & $\begin{array}{l}\text { Does Community and } \\
\text { Environmental } \\
\text { Responsibility Affect Firm } \\
\text { Risk? Evidence from UK } \\
\text { Panel Data 1994-2006 }\end{array}$ & $\begin{array}{l}\text { Business Ethics: A } \\
\quad \text { European } \\
\text { Review }\end{array}$ & $\mathrm{C}$ & 1994-2006 & 3,153 \\
\hline 36 & $\begin{array}{l}\text { Solomon et al. } \\
\quad \text { (2011) }\end{array}$ & $\begin{array}{l}\text { Private Climate Change } \\
\text { Reporting: An Emerging } \\
\text { Discourse of Risk and } \\
\text { Opportunity? }\end{array}$ & $\begin{array}{l}\text { Accounting, } \\
\text { Auditing \& } \\
\text { Accountability } \\
\text { Journal }\end{array}$ & B & 2007-2008 & 20 \\
\hline 37 & $\begin{array}{l}\text { Sharfman and } \\
\text { Fernando } \\
(2008)\end{array}$ & $\begin{array}{l}\text { Environmental Risk } \\
\text { Management and the Cost } \\
\text { of Capital }\end{array}$ & $\begin{array}{l}\text { Strategic } \\
\quad \text { Management } \\
\text { Journal }\end{array}$ & A & 2002 & 546 \\
\hline 38 & $\begin{array}{l}\text { Weber } \text { et al. } \\
\quad(2008)\end{array}$ & $\begin{array}{l}\text { Empirical Analysis of the } \\
\text { Integration of } \\
\text { Environmental Risks Into } \\
\text { the Credit Risk } \\
\text { Management Process of } \\
\text { European Banks }\end{array}$ & $\begin{array}{l}\text { Business Strategy } \\
\text { and the } \\
\text { Environment }\end{array}$ & B & 2005 & 50 \\
\hline
\end{tabular}


Table A.2. Overview of Search Results per Database and Search String (Accessed: May 30, 2019).

\begin{tabular}{|c|c|c|c|c|}
\hline $\begin{array}{l}\text { ID } \\
\text { EB }\end{array}$ & $\begin{array}{l}\text { Search string } \\
\text { ost }\end{array}$ & $\begin{array}{l}\text { Hits } \\
\text { (Engl.) } \\
191\end{array}$ & $\begin{array}{l}\text { Hits } \\
(\geq 2008) \\
126\end{array}$ & $\begin{array}{l}\text { Hits } \\
\text { (Relevant) } \\
\quad 45\end{array}$ \\
\hline 1 & $\begin{array}{l}\text { TI (environmental risk* OR carbon risk* OR climate risk* OR } \\
\text { ESG risk* OR transition risk } * \text { ) AND AB (financ* OR bank* } \\
\text { OR investor*) AND AB approach }\end{array}$ & 27 & 20 & 8 \\
\hline 2 & $\begin{array}{l}\text { TI (environmental risk* OR carbon risk* OR climate risk } * \text { OR } \\
\text { ESG risk* OR transition risk } * \text { ) AND AB (financ* OR bank* } \\
\text { OR investor*) AND AB assessment }\end{array}$ & 28 & 13 & 3 \\
\hline 3 & $\begin{array}{l}\text { TI (environmental risk } * \text { OR climate risk } * \text { OR ESG risk } * \text { OR } \\
\text { transition risk } * \text { ) AND AB (financ* OR bank* OR investor } * \text { ) } \\
\text { AND AB management }\end{array}$ & 94 & 60 & 17 \\
\hline 4 & $\begin{array}{l}\text { TI (environmental risk* OR carbon risk* OR climate risk* OR } \\
\text { ESG risk* OR transition risk } * \text { ) AND AB (financ* OR bank* } \\
\text { OR investor*) AND AB performance }\end{array}$ & 31 & 23 & 12 \\
\hline 5 & $\begin{array}{l}\text { TI (environmental risk* OR carbon risk* OR climate risk* OR } \\
\text { ESG risk* OR transition risk } * \text { ) AND AB (financ* OR bank* } \\
\text { OR investor*) AND AB pricing }\end{array}$ & 11 & 10 & 5 \\
\hline \multicolumn{2}{|c|}{ Emerald Insight } & 20 & 17 & 6 \\
\hline 6 & $\begin{array}{l}\text { [Content Item Title: environmental risk } * \text { OR carbon risk } * \text { OR } \\
\text { climate risk } * \text { OR ESG risk } * \text { OR transition risk } * \text { ] AND } \\
\text { [Abstract: financ* OR bank* OR investor* ] AND [Abstract: } \\
\text { approach] }\end{array}$ & 8 & 8 & 2 \\
\hline 7 & $\begin{array}{l}\text { [Content Item Title: environmental risk* OR carbon risk } * \text { OR } \\
\text { climate risk } * \text { OR ESG risk } * \text { OR transition risk } * \text { ] AND } \\
\text { [Abstract: financ } * \text { OR bank* OR investor* ] AND [Abstract: } \\
\text { assessment] }\end{array}$ & 2 & 1 & 0 \\
\hline 8 & $\begin{array}{l}\text { [Content Item Title: environmental risk* OR carbon risk } * \text { OR } \\
\text { climate risk } * \text { OR ESG risk } * \text { OR transition risk } * \text { ] AND } \\
\text { [Abstract: financ } * \text { OR bank* OR investor* ] AND [Abstract: } \\
\text { management] }\end{array}$ & 6 & 4 & 2 \\
\hline 9 & $\begin{array}{l}\text { [Content Item Title: environmental risk } * \text { OR carbon risk } * \text { OR } \\
\text { climate risk } * \text { OR ESG risk } * \text { OR transition risk } * \text { ] AND } \\
\text { [Abstract: financ } * \text { OR bank } * \text { OR investor } * \text { ] AND [Abstract: } \\
\text { performance] }\end{array}$ & 3 & 3 & 2 \\
\hline 10 & $\begin{array}{l}\text { [Content Item Title: environmental risk } * \text { OR carbon risk } * \text { OR } \\
\text { climate risk } * \text { OR ESG risk } * \text { OR transition risk } * \text { ] AND } \\
\text { [Abstract: financ } * \text { OR bank } * \text { OR investor } * \text { ] AND [Abstract: } \\
\text { pricing] }\end{array}$ & 1 & 1 & 0 \\
\hline \multicolumn{2}{|c|}{ ScienceDirect } & 167 & 151 & 13 \\
\hline 11 & $\begin{array}{l}\text { TITLE ((environmental risk*) OR (carbon risk*) OR (climate } \\
\text { risk } * \text { ) OR (ESG risk*) OR (transition risk*)) and } \\
\text { TITLE-ABSTR-KEY (((financial) OR (finance) OR (bank) OR } \\
\text { (banking) OR (investor)) AND (approach)) }\end{array}$ & 23 & 22 & 3 \\
\hline
\end{tabular}


Table A.2. Continued.

\begin{tabular}{|c|c|c|c|c|}
\hline $\begin{array}{l}\text { ID } \\
\mathbf{E B}\end{array}$ & $\begin{array}{l}\text { Search string } \\
\text { st }\end{array}$ & $\begin{array}{l}\text { Hits } \\
(\text { Engl.) } \\
191\end{array}$ & $\begin{array}{l}\text { Hits } \\
(\geq 2008) \\
126\end{array}$ & $\begin{array}{l}\text { Hits } \\
\text { (Relevant) } \\
\quad 45\end{array}$ \\
\hline 12 & $\begin{array}{l}\text { TITLE ((environmental risk } * \text { ) OR (carbon risk } * \text { ) OR (climate } \\
\text { risk } * \text { ) OR (ESG risk } * \text { ) OR (transition risk } *) \text { ) and } \\
\text { TITLE-ABSTR-KEY (((financial) OR (finance) OR (bank) OR } \\
\text { (banking) OR (investor)) AND (assessment)) }\end{array}$ & 31 & 25 & 2 \\
\hline 13 & $\begin{array}{l}\text { TITLE ((environmental risk } * \text { ) OR (carbon risk } * \text { ) OR (climate } \\
\text { risk } * \text { ) OR (ESG risk } * \text { ) OR (transition risk } *) \text { ) and } \\
\text { TITLE-ABSTR-KEY (((financial) OR (finance) OR (bank) OR } \\
\text { (banking) OR (investor)) AND (management)) }\end{array}$ & 44 & 41 & 5 \\
\hline 14 & $\begin{array}{l}\text { TITLE ((environmental risk*) OR (carbon risk*) OR (climate } \\
\text { risk*) OR (ESG risk*) OR (transition risk } *) \text { ) and } \\
\text { TITLE-ABSTR-KEY (((financial) OR (finance) OR (bank) OR } \\
\text { (banking) OR (investor)) AND (performance)) }\end{array}$ & 14 & 12 & 3 \\
\hline 15 & $\begin{array}{l}\text { TITLE ((environmental risk } * \text { ) OR (carbon risk } * \text { ) OR (climate } \\
\text { risk } * \text { ) OR (ESG risk } * \text { ) OR (transition risk } *) \text { ) and } \\
\text { TITLE-ABSTR-KEY (((financial) OR (finance) OR (bank) OR } \\
\text { (banking) OR (investor)) AND (pricing)) }\end{array}$ & 25 & 22 & 0 \\
\hline \multicolumn{2}{|c|}{ Sum in total } & 378 & 296 & 64 \\
\hline \multicolumn{2}{|c|}{ Sum in total (without duplication) } & & & 35 \\
\hline \multicolumn{2}{|c|}{ Sum in total (without duplication, VHB rating $\mathrm{C}+$ ) } & & & 19 \\
\hline
\end{tabular}

Table A.3. Snowball Principle Literature Overview.

\begin{tabular}{|c|c|c|c|c|}
\hline ID & Authors (Year) & Access & Rating & References \\
\hline 1 & Ilhan et al. (2020a) & Yes & - & 2,3 \\
\hline 2 & Solomon et al. (2011) & Yes & B & - \\
\hline 3 & Ilhan et al. (2020b) & Yes & $\mathrm{A}+$ & $4,7,12$ \\
\hline 4 & Görgen et al. (2019) & Yes & - & $5,6,7,8,9,10,11$ \\
\hline 5 & Barnett et al. (2020) & Yes & $\mathrm{A}+$ & 21 \\
\hline 6 & Chava (2014) & Yes & $\mathrm{A}+$ & 19 \\
\hline 7 & Delis et al. (2020) & Yes & $\mathrm{A}+$ & - \\
\hline 8 & Engle et al. (2020) & Yes & $\mathrm{A}+$ & - \\
\hline 9 & Fernando et al. (2017) & Yes & A & - \\
\hline 10 & Flammer (2013) & Yes & $\mathrm{A}+$ & - \\
\hline 11 & Krueger et al. (2020) & Yes & $\mathrm{A}+$ & $5,6,9,12,13,14^{\mathrm{a}}, 15,16,17,18,19,20$ \\
\hline 12 & Andersson et al. (2016b) & Yes & $\mathrm{B}$ & - \\
\hline 13 & Andersson et al. (2016a) & Yes & $\mathrm{C}$ & 12 \\
\hline 14 & Addoum et al. (2020) & Yes & $\mathrm{A}+$ & - \\
\hline
\end{tabular}

(Continued) 
Table A.3. (Continued).

\begin{tabular}{lcccc}
\hline \hline ID & Authors (Year) & Access & Rating & References \\
\hline 15 & Addoum et al. (2019) & Yes & - & - \\
16 & Eccles and Krzus (2018) & Yes & C & - \\
17 & Alok et al. (2020) & Yes & A & 18 \\
18 & Hong et al. (2019) & Yes & - & - \\
19 & Litterman (2011) & Yes & B & - \\
20 & Sharfman and Fernando (2008) & Yes & A & - \\
21 & Bansal et al. (2016) & Yes & - & -
\end{tabular}

${ }^{\text {a }}$ The study referenced in Krueger et al. (2020) has been split into the two publications, namely, Addoum et al. (2020) [14] and Addoum et al. (2019) [15]. 